University of South Carolina

Scholar Commons

Theses and Dissertations

2015

Dissolved and Particulate Phosphorus Distributions and Elemental Stoichiometry Throughout the Chukchi Sea

Meryssa Piper

University of South Carolina

Follow this and additional works at: https://scholarcommons.sc.edu/etd

Part of the Marine Biology Commons

Recommended Citation

Piper, M.(2015). Dissolved and Particulate Phosphorus Distributions and Elemental Stoichiometry Throughout the Chukchi Sea. (Master's thesis). Retrieved from https://scholarcommons.sc.edu/etd/3671

This Open Access Thesis is brought to you by Scholar Commons. It has been accepted for inclusion in Theses and Dissertations by an authorized administrator of Scholar Commons. For more information, please contact digres@mailbox.sc.edu. 


\title{
Dissolved AND PARTICUlate PHOSPHORUS DisTRIBUTIONS AND ELEMENTAL STOICHIOMETRY THROUGHOUT THE CHUKCHI SEA
}

\author{
by \\ Meryssa Piper \\ Bachelor of Science \\ University of South Carolina, 2012
}

Submitted in Partial Fulfillment of the Requirements

For the Degree of Master of Science in

Marine Science

College of Arts and Sciences

University of South Carolina

2015

Accepted by:

Claudia Benitez-Nelson, Director of Thesis

Lori Ziolkowski, Reader

Tammi Richardson, Reader

Lacy Ford, SeniorVice Provost and Dean of Graduate Studies 
(C) Copyright by Meryssa M. Piper, 2015 All Rights Reserved. 


\section{DEDICATION}

To my parents, who have given their all to prepare me for life's curves.

My best friends, may the time and effort you put into helping me be paid off with interest.

And to my husband, who has given me his time, support and patience. To many more chapters! 


\section{ACKNOWLEDGEMENTS}

I would like to begin by thanking my committee for their patience and support throughout my thesis work. Dr. Claudia Benitez-Nelson, my main advisor, whom over the past several years has provided mentorship aiding both in my personal and professional experiences. Dr. Tammi Richardson, without whom I would have never comprehended the biological workings of this project as well as oceanography as a whole. Finally Dr. Lori Ziolkowski, who has consistently pushed me to think outside of my realm. I am indebted to these women, as they have provided me with the skills to stand my ground, worked diligently with me to bestow upon me the ability to communicate across broad outlooks, and have proved excellent mentors both as women and scientists.

A special appreciation must also be extended to my lab mates present and past, former lab manager, Wendy Plessinger, family and friends. Blaire Umhau, Doug Bell, Mariella Monge, and Kelly McCabe, who learned with me and provided encouragement each step of the way. Annie Opseth and Sharmila Pal who provided mentorship and friendship as senior graduate students. Daniel Wade, Victoria Garefino, and Emily Palmer, who were patient with me as I learned to teach the phosphorus method. Wendy Plessinger who taught me most everything I know about analytical chemistry, was patient with me through my hard days, and always made a point to celebrate my good days. Lastly my close friends and family, for putting up with my hectic schedule and various attitudes, I couldn't have done it without you! 


\begin{abstract}
As the only gateway of material, particularly nutrients, from the Pacific to the Arctic Ocean, the biological and chemical transformations that occur within the Chukchi Sea are critical for understanding Arctic ecosystems. This study examines the biogeochemical cycling of the macronutrient phosphorus $(\mathrm{P})$ relative to carbon and nitrogen in the eastern Chukchi Sea during the ICESCAPE's mission. Sea ice and water column dissolved and particulate phosphorus samples were collected during two summer expeditions in $2010(n=593)$ and $2011(n=989)$. Despite being a landlocked marginal sea, the P pool present within the Chukchi Sea was substantially modified by biological processes with $30-40 \%$ of the total dissolved pool (TDP) comprised of organic P (DOP) and nearly $50 \%$ of total particulate $\mathrm{P}$ comprised of organic P forms. Surprisingly the offshore waters held significantly higher concentrations of $\mathrm{P}$ in all forms throughout the Chukchi Sea $\left(\mathrm{TP}_{2010}=1.54 \pm 0.64 \mu \mathrm{M}, \mathrm{TP}_{2011}=1.58 \pm 0.67 \mu \mathrm{M} ; \pm 1\right.$ standard deviation $)$, suggesting coastal inputs of $\mathrm{P}$ were relatively small during our sampling. This increase offshore highlights the potential importance of sea ice melt in the addition of nutrients to the surface waters. Upon the examination of ice cores collected, this study suggests that the impact of sea ice melt depends heavily on whether the ice is clean or sediment-laden, as their particulate $\mathrm{C}: \mathrm{N}: \mathrm{P}$ ratios vary by over a factor of 10 . The dissolved data also suggests the potential for $\mathrm{N}: \mathrm{P}$ to be altered in favor nitrogen from 0.44 to 0.64 , though overall concentrations would be diluted throughout the mixed layer.
\end{abstract}




\section{TABLE OF CONTENTS}

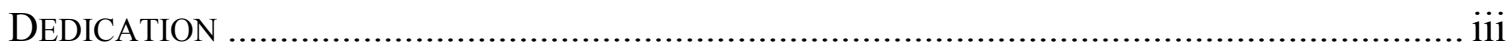

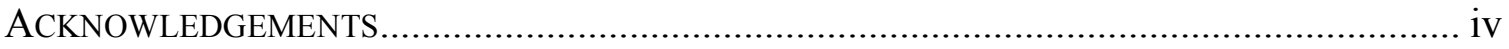

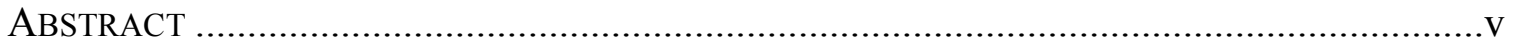

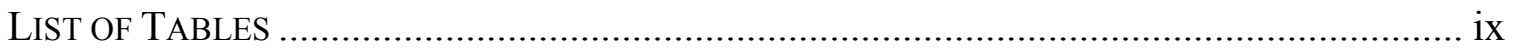

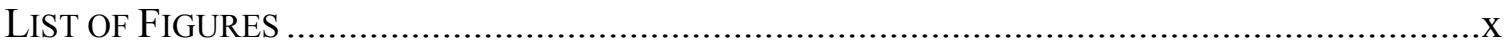

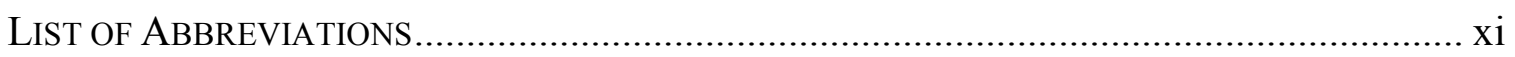

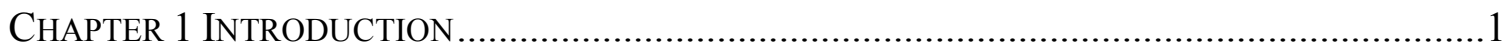

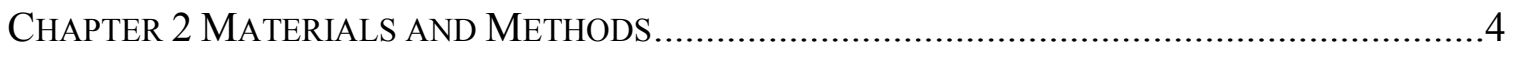

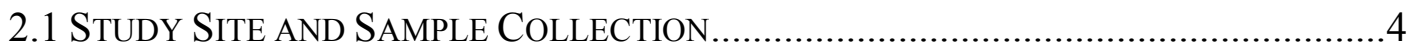

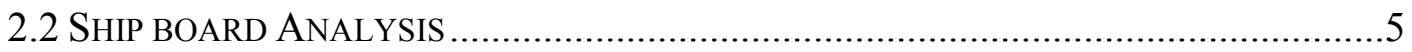

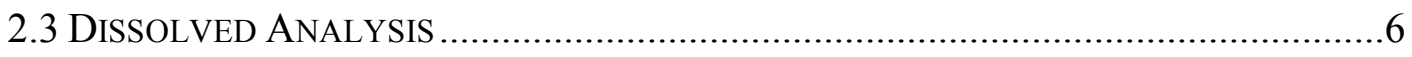

2.4 PARTICULATE ANALYSIS ...............................................................................

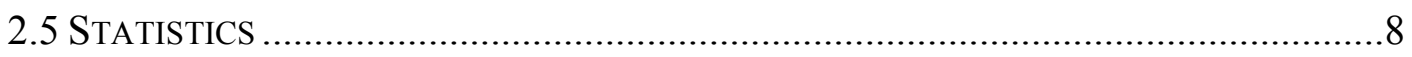

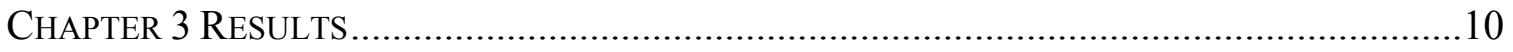

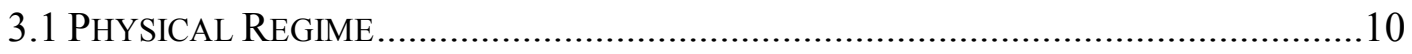

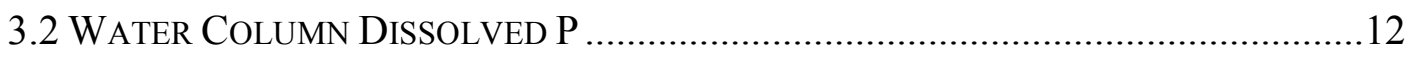

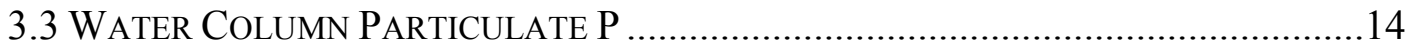

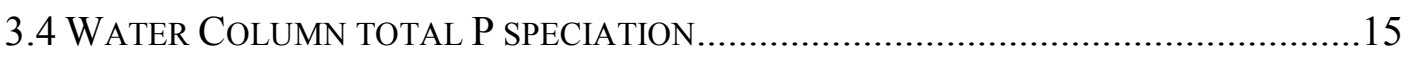

3.5 Water Column Elemental StoIChiometry ................................................17

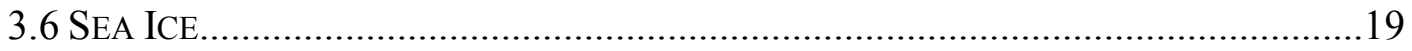




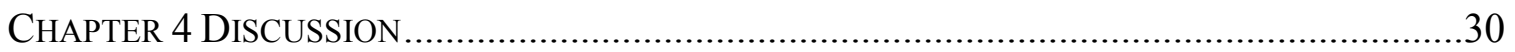

4.1 RIVERINE INPUTS AND BOTTOM RESUSPENSION..................................................30

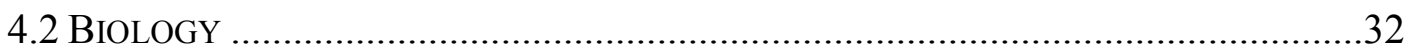

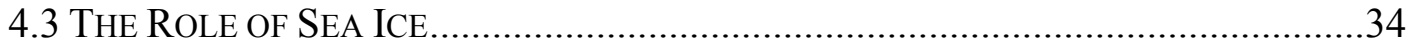

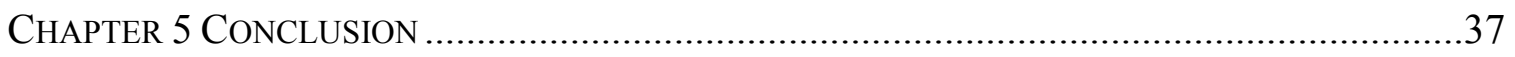

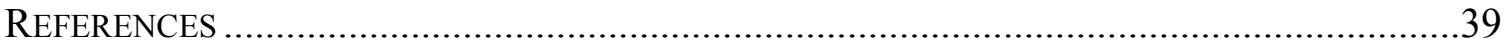




\section{LIST OF FIGURES}

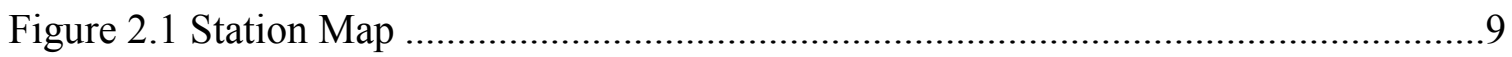

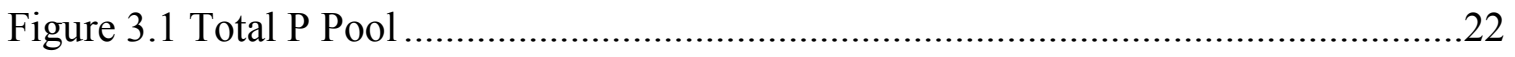

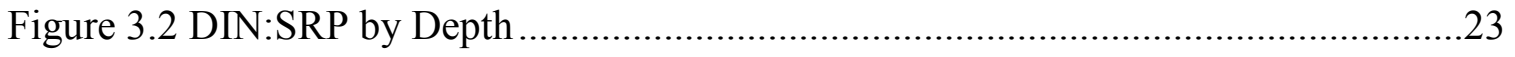

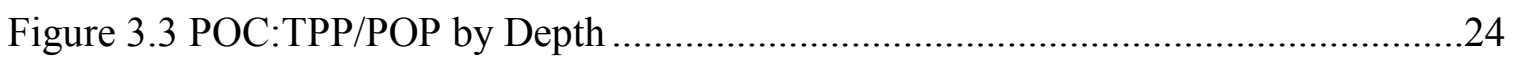

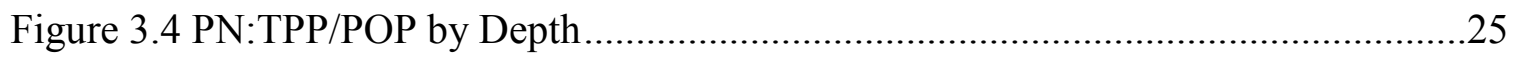

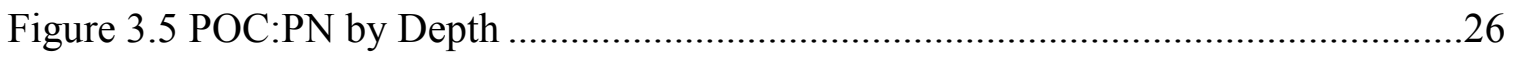

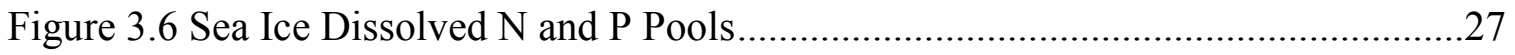

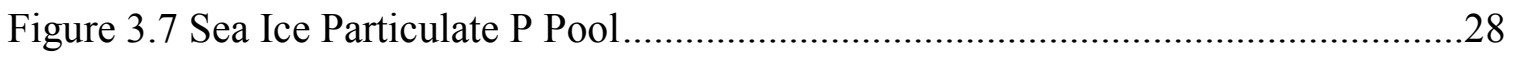

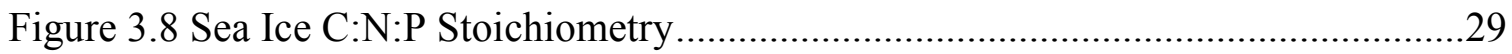




\section{LIST OF ABBREVIATIONS}

PIP




\section{CHAPTER 1}

\section{INTRODUCTION}

The Arctic Ocean is undergoing significant changes in its physical and biogeochemical environment due to rising water temperatures, melting sea ice, and increases in riverine drainage (Arnell 2005, Serreze et al. 2007, Stroeve et al. 2012, Post et al. 2013). The 2007-2010 average September sea ice extent shows a $40 \%$ decline compared to measurements taken 20-30 years ago (Stroeve et al. 2012). Sea ice distributions reached record lows in 2012. Furthermore models suggest that the entire Arctic will become seasonally ice free as early as 2040 (Holland et al. 2006, Wang and Overland 2009). Indeed, some Arctic seas have already begun to experience ice free seasons, including the Chukchi Sea (Stroeve et al. 2012). Coincident with this loss of sea ice, is a significant increase in primary production, mainly due to open water expansion and duration of the open water season (Arrigo and van Dijken 2011). This increase in water column primary production occurs simultaneously with dwindling sea ice primary production, which likely contributes greater than $50 \%$ of the annual primary production within the central Arctic (Gosselin et al. 1997). Sea ice loss also influences the timing of blooms (allowing for blooms to occur earlier in the season with greater sunlight penetration), disrupts predation, and may provide an important source of food to pelagic and benthic biota (Leu et al. 2011).

As nutrient rich Pacific waters make their way through the only pathway to the Arctic, the Chukchi Sea via the Bering Strait, they are impacted by a variety of processes, 
including coastal inputs, sediment resuspension, redox reactions (e.g., denitrification), variable ice cover, and primary production (Frey et al. 2014). Similar to the rest of the Arctic Ocean, the Chukchi Sea has experienced an increase in water column primary production of almost $50 \%$ over the past 15 years, one of the highest increases in primary production throughout the region. This dramatic increase is likely due to greater light penetration as a result of declining sea ice and enhanced melt ponding .,(Arrigo and van Dijken 2011, Frey et al. 2011, Grebmeier 2012, Petrenko et al. 2013). It is important to note, however, these estimates do not include primary productivity within or beneath sea ice, such as the massive under ice bloom observed in 2011 (Arrigo et al. 2012). Furthermore, nearly $70 \%$ of the resulting carbon fixed in the southeast Chukchi from water column primary production is believed to settle to the sea floor where it can be utilized by benthic fauna (Cooney and Coyle 1982, Walsh et al. 1989, McTigue et al. 2015).

Over the last decade, Pacific waters transported from the Chukchi into the Beaufort Sea have declined by over $80 \%$, despite the increase of water flow through the Bering Strait (Brugler et al. 2014). Most of this decline has occurred during the summer months; thus it is hypothesized that the intensifying summer easterly winds, which counteract the north easterly flowing current along the shelf, are to blame for this large scale decline (Moore 2012, Brugler et al. 2014, Frey et al. 2015). Modifications in water circulation potentially impacts the magnitude and composition of the nutrients supplied to the Arctic Ocean as well as biogeochemical cycling in the north Chukchi and Beaufort seas. 
Phosphorus $(\mathrm{P})$ is an essential macronutrient that influences biological production and community structures in a variety of marine systems (Karl 2014). Within the ocean, P occurs in both organic and inorganic forms and is actively partitioned between dissolved and particulate phases via a suite of biologically and chemically mediated reactions. While many previous studies have focused mainly on inorganic $\mathrm{P}$, as it is the most readily available form (e.g., Benitez-Nelson 2000, Paytan and McLaughlin 2007) numerous studies now recognize that organisms also utilize organic $\mathrm{P}$ compounds even when inorganic P concentrations are relatively high $(>0.2 \mu \mathrm{M})$ (e.g., Mortazavil et al. 2000, Dyhrman et al. 2006, Sylvan et al. 2006, Huang and Zhang 2010, Karl 2014). Therefore, understanding the distribution and concentrations of all $\mathrm{P}$ forms is critical for examining nutrient dynamics. Nevertheless, relatively little is known regarding its distribution within marine dissolved and particulate matter in the Arctic Ocean, particularly in the Chukchi Sea. In this study, we analyzed multiple water column and sea ice core samples for dissolved and particulate $\mathrm{P}$ that were collected throughout the eastern Chukchi Sea during the summers of 2010 and 2011 as part of the NASA's Impact of Climate Change on the Ecosystems and Chemistry of the Arctic Pacific Environment (ICESCAPE) Mission. The goal of this study was to improve our understanding of the source, composition, and distribution of dissolved and particulate $\mathrm{P}$ within this climate impacted ecosystem. 


\section{CHAPTER 2}

\section{MATERIALS AND METHODS}

\subsection{Study Site and Sample Collection}

As part of the ICESCAPE field mission, the Chukchi Sea was sampled during two summer cruises, 15 June - 22 July 2010 and 25 June - 29 July 2011 aboard the USCGC Healy (Figure 2.1). During the 2010 cruise, 140 water column $(n=135)$ and ice $(n=10)$ stations were sampled from the Bering Strait northward to Barrow Canyon. Dissolved and/or particulate $\mathrm{P}$ were sampled from 121 of these stations with 543 samples analyzed. Due to decreased ice cover, the 2011 cruise extended from the Bering Strait northward to the southern Beaufort Sea; 173 stations were sampled, including nine ice core stations. Dissolved and/or particulate data was analyzed in 553 samples from 104 stations. All ice stations were comprised of only first year ice. Both cruises encompassed sections of major water masses. The Alaska Coastal Waters were identified by high temperatures $\left(>2^{\circ} \mathrm{C}\right)$ and salinities between 30 and 33.64, while the Chukchi Summer Waters were characterized by lower temperatures $\left(-1-2^{\circ} \mathrm{C}\right)$, but with similar salinities (Brugler et al. 2014). Bering Strait waters, while present, were more difficult to distinguish due to solar warming of the mixed layer and relatively limited knowledge regarding its flow path (Coachman et al. 1975). Atlantic deep waters were also sampled and characterized by low temperatures $\left(<-1.26^{\circ} \mathrm{C}\right)$ and high salinities (> 33.64) (Brugler et al. 2014). Water column data was obtained by deploying a conductivity, temperature, and depth sensor (CTD) on a rosette system equipped with twelve $10 \mathrm{~L}$ 
Niskin bottles. The CTD/rosette system also included a photosynthetically available radiation (PAR) sensor, and a fluorometer. Water samples were collected at various depths (roughly $2,10,25,50,100,200,500,1000$, and $2000 \mathrm{~m}$ depending on water depth) and analyzed for chlorophyll a, and dissolved inorganic nutrients (i.e. nitrate silicate, phosphate).

Ice core data was collected using a custom built CRREL ice coring system with a diameter of $10 \mathrm{~cm}$. Cores used for nutrient analysis during the 2010 cruise $(\mathrm{n}=21)$ were melted in a known amount of filtered surface seawater (usually $2 \mathrm{~L}$ per $10 \mathrm{~cm}$ section), with salinity measurements recorded pre and post melt. As such, no dissolved nutrient data are available. These waters were then filtered for particulate $\mathrm{P}$ analysis onto a $1 \mathrm{~N} \mathrm{HCl}$ washed and $500^{\circ} \mathrm{C}$ combusted $25 \mathrm{~mm} \mathrm{GF} / \mathrm{F}$ filter $(\sim 0.7 \mu \mathrm{m})$ and frozen until lab analysis. In 2011, the ice cores used for nutrient analysis were melted without dilution. Particulate and dissolved nutrient analyses were conducted on the resulting melt water. During the 2010 cruise, there were visibly sediment laden sea ice cores, which were later separated for comparison based on visual differences.

\subsection{Ship board Analysis}

Fluorescence data were collected at each station using a Wetlabs Chlorophyll fluorometer. Additional samples for chlorophyll a analysis were filtered onto a $25 \mathrm{~mm}$ Whatman $\mathrm{GF} / \mathrm{F}(\sim 0.7 \mu \mathrm{m})$ filter, placed in $5 \mathrm{~mL}$ of $90 \%$ acetone and extracted in the dark at $3^{\circ} \mathrm{C}$ for 24 hours. Chlorophyll a concentrations were then measured fluorometrically using a Turner fluorometer 10-Au (Holm-Hansen et al. 1965). Extracted chlorophyll measurements were used to calibrate fluorescence based chlorophyll a measurements in remaining samples (Arrigo et al. 2014). 
Total inorganic nutrients (unfiltered) were analyzed on a segmented continuous flow auto analyzer within a few hours of collection on the ship. $\left[\mathrm{NO}_{3}^{-}\right],\left[\mathrm{NO}_{2}{ }^{-}\right]$and $\left[\mathrm{Si}(\mathrm{OH})_{4}\right]$ analysis was performed using a modification of the method outlined by Armstrong et al. (1967). While $\left[\mathrm{NH}_{4}^{+}\right]$was determined fluorometrically according to Kérouel and Aminot (1997), and $\left[\mathrm{H}_{2} \mathrm{PO}_{4}{ }^{-}\right]$was measured using the ammonium molybdate method described in Bernhardt and Wilhelms (1967) (Brown et al. 2015).

\subsection{Dissolved Analysis}

Dissolved P samples were collected by filtering $\sim 40 \mathrm{~mL}$ of seawater through a $500^{\circ} \mathrm{C}$ pre-combusted and $1 \mathrm{~N} \mathrm{HCl}$ washed, $25 \mathrm{~mm} \mathrm{GF} / \mathrm{F}$ filter $(\sim 0.7 \mu \mathrm{m})$ and frozen until analysis. Soluble reactive P (SRP) was measured according to the spectrophotometric method described in Koroleff (1983). Total dissolved P (TDP) was measured by the high temperature ash/hydrolysis technique outlined in Monaghan and Ruttenberg (1999). Both SRP and TDP analyses have a detection limit of $0.07 \mu \mathrm{M}$. Dissolved organic P (DOP) was calculated based on the difference between the two measurements, i.e. TDP - SRP = DOP. Approximately $11 \%$ of samples were run in duplicate, with an average coefficient of variation $(\mathrm{CV})$ of $6.0 \pm 5.2 \%$. It is important to note that SRP and DOP are analytically defined; therefore SRP may contain acid-labile organic compounds, such as simple sugars, while DOP may contain acid insoluble inorganic compounds, such as polyphosphates (Monaghan and Ruttenberg 1999, Benitez-Nelson 2000). Comparison of ship board auto-analysis versus laboratory SRP measurements found that auto-analyzed P values were on average $13 \%$ greater than filtered SRP concentrations, likely due to the presence of reactive particulate $P$. 


\subsection{Particulate Analysis}

Samples for particulate nitrogen (PN) and particulate organic carbon (POC) were filtered onto a pre-combusted $25 \mathrm{~mm}$ Whatman $\mathrm{GF} / \mathrm{F}$ filter $(\sim 0.7 \mu \mathrm{m})$ and stored frozen until analysis. The POC filters were fumed in a desiccator with concentrated $\mathrm{HCl}$. The PN and POC samples were subsequently dried at $60^{\circ} \mathrm{C}$, and packed into tin capsules for elemental analysis. Peach leaves and glutamic acid were used as calibration standards for PN and POC (Mills et al. 2015). Particulate P samples were filtered onto a $500^{\circ} \mathrm{C}$ precombusted, $1 \mathrm{~N} \mathrm{HCl}$ washed $25 \mathrm{~mm}$ Whatman GF/F filter $(\sim 0.7 \mu \mathrm{m})$, frozen and stored until analysis. Ice core particulate total carbon (PC) and PN were analyzed from surplus $\mathrm{P}$ filters.

Total particulate phosphorus (TPP) and particulate inorganic phosphorus (PIP) were analyzed according to the ash/hydrolysis method outlined by Aspila et al. (1976) as modified by Benitez-Nelson et al. (2007). Particulate organic phosphorus (POP) was determined by the difference, i.e. TPP $-\mathrm{PIP}=$ POP. Recovery efficiency and reproducibility for each sample set was assessed from the quadruplicate analysis of two certified reference materials (NIST 1515, tomato leaves, certified $0.216 \% \mathrm{P}$ by weight, and NIST 1673a, estuarine sediment, certified $0.027 \% \mathrm{P}$ by weight). The distinction between PIP and POP concentrations is again operationally defined. Therefore it is probable that the inorganic $\mathrm{P}$ fraction contains some labile organic $\mathrm{P}$ compounds and vice versa (Benitez-Nelson et al. 2004). Approximately, $5 \%$ of the samples were run in duplicate, with average $\mathrm{CV}$ of $5.3 \pm 3.9 \%$. Average GF/F filter blanks were below the $0.07 \mu \mathrm{M}$ P limit of detection. 


\subsection{Statistics}

All data sets were tested for normality using the Lillifor's significance correction K-S test (Lilliefors 1967). Much of the data experiences small departures from normality. Due to their robust nature, parametric t-tests were used to determine significant differences $(p \leq 0.05)$. One standard deviation is presented alongside all arithmetic means and as error bars. When summed data are presented instead of means, total errors are propagated using the analytical uncertainties of each measurement. 


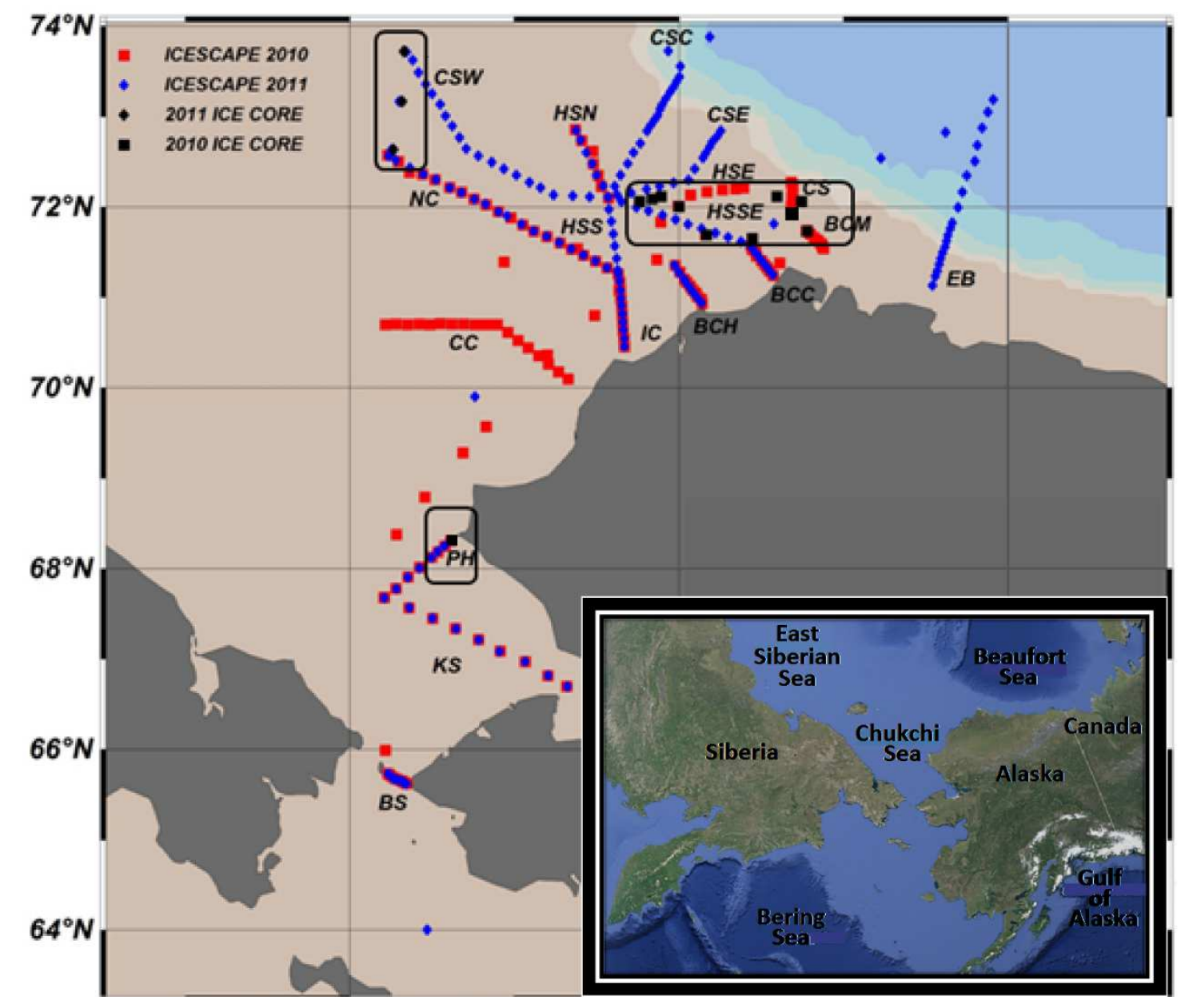

Figure 2.1: Station Map. 2011 (blue) and 2010 (red) with ice stations for both years (black); ice stations further emphasized with black rectangles. Sections of the cruise were grouped and labeled for comparison; Bering Strait (BS), Kotzebue Sound (KS), Point Hope (PH), Center Channel (CC), Icy Cape (IC), North Chukchi (NC), Hanna Shoal South (HSS), Chukchi Slope West (CSW), Hanna Shoal North (HSN), Barrow Canyon Head (BCH) Barrow Canyon Center (BCC) Hanna Shoal South East (HSSE), Hanna Shoal East (HSE), Chukchi Slope East (CSE), Chukchi Slope Center (CSC), Barrow Canyon Mouth (BCM), Chukchi Slope (CS), and East of Barrow (EB). 


\section{CHAPTER 3}

RESULTS

\subsection{Physical Regime}

Waters make their way through the eastern Chukchi Sea in one of two major water masses: the Alaskan Coastal Waters or the Chukchi Summer Waters (von Appen and Pickart 2012, Brugler et al. 2014), which is also referred to as Bering Sea Water (Gong and Pickart 2015), Summer Bering Sea Water (Steele et al. 2004), and Eastern Chukchi Summer Water (Shimada et al. 2001). The Alaskan Coastal Waters are pumped through the Chukchi Sea by the Alaskan Coastal Current (ACC) and remain trapped within 50 m of the coast (Schumacher and Reed 1986). However, the Chukchi Summer Waters (CSW) move through the Chukchi Sea in a variety of pathways. These waters enter into the Arctic Ocean via four main routes: Long Strait, Herald Valley, Central Channel, and Barrow Canyon. Barrow Canyon is the fastest flowing output with rates up to $1 \mathrm{~Sv}$ during the summer months, and is the major exit pathway assessed in this study (Münchow et al. 1999, Weingartner et al. 2005). As waters exit Barrow Canyon, they are squeezed into the Beaufort Shelf Jet, a narrow shelf break, as they make their way into the Beaufort Sea (Pickart 2004, Nikolopoulos et al. 2009).

Between the 2010 and 2011 cruises, important differences in the physical regime

of the water column were observed. During the 2011 cruise, sea ice retreat was extensive, allowing samples to be collected farther into the Chukchi Sea and into the Beaufort Sea. This alteration in ice melt may have been caused in part by the increase in warm, fresh 
waters entering Kotzebue Sound from the Noatak, Selawik, and Kobuk Rivers. The warm water intrusion also resulted in an increase in stratification in 2011 relative to 2010. The ACC was notably less constrained during 2011 and mixed with the Chukchi Summer Waters. These water masses are therefore more difficult to identify, particularly in the northern region. The Chukchi Sea Environmental Studies Program noted that the winds during 2010 were weaker and more variable from July to September, while the 2011 northeasterly winds were more prominent and lasted from June to October (www.Chukchiscience.com/science, 7 Nov. 2014). These winds contributed to the observed decrease in the ACC strength, and a reduction in the Beaufort Shelf Jet during 2011 compared to that of 2010.

In order to better understand spatial and temporal differences, data were sorted by year, transect, depth (mixed layer, mid waters, and bottom waters) as well as overall region and water mass (inshore of ACC, referred to as inshore, the ACC, and offshore of ACC waters, referred to as offshore). ACC waters were separated by specific sampling depths according to measured temperatures and salinities (See Section 2.1) rather than by entire stations, as many stations did not contain ACC waters throughout all depths (Figure 3.1). Seventeen transects were analyzed, nine of which were sampled during both cruises (Figure 2.1). The Barrow Canyon Center transect was chosen for direct comparison to the Bering Strait transect because the Beaufort Shelf jet is a major outflow pathway of ACC waters into the Arctic Ocean, and thus reflects the alterations that occur to Pacific waters as they travel through the Chukchi Sea. Mixed layer depths were determined by density differences greater than 0.125 corresponding to temperature differences of $0.5^{\circ} \mathrm{C}$ as outlined by Monterey and Levitus (1997), with an average mixed 
layer depth of $9 \pm 8 \mathrm{~m}$ in 2010 and $9 \pm 7 \mathrm{~m}$ in 2011 . Bottom waters were defined as all waters within $5 \mathrm{~m}$ of seafloor, and middle waters are defined as all waters falling between the mixed layer and bottom waters.

3.2 Water Column Dissolved P

Dissolved P concentrations within the Chukchi Sea varied widely, from a minimum of $0.39 \mu \mathrm{M}$ in the mid waters of Kotzebue Sound in 2011, to a maximum of 3.61 $\mu \mathrm{M}$ within mid waters of Chukchi Slope West in 2011. Mixed layer SRP concentrations ranged from 0.11 to $1.97 \mu \mathrm{M}$ and averaged $0.60 \pm 0.35 \mu \mathrm{M}$ and $0.58 \pm$ $0.21 \mu \mathrm{M}$ in 2010 and 2011. DOP concentrations ranged from $<0.07 \mu \mathrm{M}$ to $2.06 \mu \mathrm{M}$ averaging $0.52 \pm 0.32 \mu \mathrm{M}(46 \pm 18 \%$ of TDP $)$ and $0.46 \pm 0.23 \mu \mathrm{M}(43 \pm 15 \%$ of TDP $)$ in 2010 and 2011, respectively. There were no clear trends in either SRP or DOP with total chlorophyll a. SRP concentrations in the mid-waters varied from 0.07 to $2.24 \mu \mathrm{M}$ and was significantly higher in 2011 versus $2010,0.77 \pm 0.42 \mu \mathrm{M}$ versus $1.03 \pm 0.50 \mu \mathrm{M}$ (p $<0.001)$. Total dissolved $\mathrm{P}$ concentrations in the bottom waters had little interannual variability averaging $1.64 \pm 0.49 \mu \mathrm{M}$ and $1.63 \pm 0.60 \mu \mathrm{M}$ in 2010 and 2011 , respectively. Bottom water SRP concentrations dominated the dissolved P pool $(2010=67 \pm 19 \%$; $2011=60 \pm 23 \%$ ), ranging from 0.31 to $2.23 \mu \mathrm{M}$ and averaged $1.11 \pm 0.51 \mu \mathrm{M}$ and 1.06 $\pm 0.49 \mu \mathrm{M}$ in 2010 and 2011, respectively. DOP concentrations were significantly lower ( $\mathrm{p}<0.001$ ), ranging from $<0.7$ to $2.17 \mu \mathrm{M}$ and averaging $0.54 \pm 0.38 \mu \mathrm{M}$ and $0.60 \pm$ $0.41 \mu \mathrm{M}$ in 2010 and 2011.

Closer examination of the various water masses within the Chukchi Sea showed significant differences between ACC and non ACC waters depending on the study year (Figure 3.1). SRP concentrations were similar in offshore waters, averaging $0.80 \pm 0.46$ 
$\mu \mathrm{M}$ in 2010 and $0.94 \pm 0.49 \mu \mathrm{M}$ in 2011 . These concentrations however, were always significantly higher than inshore waters, which averaged $0.57 \pm 0.19 \mu \mathrm{M}$ and $0.49 \pm 0.13$ $\mu \mathrm{M}$, and ACC waters, which averaged $0.53 \pm 0.28 \mu \mathrm{M}$ and $0.58 \pm 0.19 \mu \mathrm{M}$ in 2010 and 2011, respectively $(\mathrm{p}<0.001)$. In 2010, DOP concentrations consistently decreased from inshore $(0.69 \pm 0.38 \mu \mathrm{M})$ to offshore $(0.50 \pm 0.36 \mu \mathrm{M} ; \mathrm{p}=0.016)$, while no significant differences were observed in 2011 (average DOP concentrations of $0.49 \pm 0.30 \mu \mathrm{M}$ ). Combined, observed water mass and temporal differences drove overall changes in TDP concentrations, with inshore waters decreasing from $1.26 \pm 0.50 \mu \mathrm{M}$ in 2010 to $1.01 \pm$ $0.15 \mu \mathrm{M}$ in $2011(\mathrm{p}=0.029)$, offshore waters increasing from $1.19 \pm 0.28 \mu \mathrm{M}$ in 2010 to $1.41 \pm 0.59 \mu \mathrm{M}$ in $2011(\mathrm{p}=0.007)$ and ACC waters remaining relatively unchanged.

On a regional basis, most of the variability observed in $\mathrm{P}$ concentrations and composition occurred within the mixed layer, with average regional SRP concentrations increasing from an average of $0.74 \pm 0.43 \mu \mathrm{M}$ in 2010 to $0.89 \pm 0.48 \mu \mathrm{M}$ in $2011(\mathrm{p}<$ 0.05) mainly due to higher SRP concentrations observed in three transects: North Chukchi, Hanna Shoal North, and Barrow Canyon Center (data not shown). In contrast, average DOP concentrations remained relatively similar, $0.52 \pm 0.36 \mu \mathrm{M}$ in 2010 and $0.49 \pm 0.30 \mu \mathrm{M}$ in 2011. High variability in both SRP and DOP concentrations throughout the region resulted in similar average TDP concentrations of $1.26 \pm 0.53 \mu \mathrm{M}$ in 2010 and $1.37 \pm 0.57 \mu \mathrm{M}$ in 2011. In comparing the dissolved P pools within waters entering (Bering Strait) to those exiting (Barrow Canyon Center) no significant concentration alterations were present within or among years (Table 1). 


\subsection{Water Column Particulate P}

Particulate P concentrations within the Chukchi Sea were lower and more variable than their dissolved counterparts and had no significant trends with depth or year. TPP ranged from $<0.07 \mu \mathrm{M}$ to a maximum of $1.44 \mu \mathrm{M}$. Mixed layer PIP concentrations ranged from $<0.7 \mu \mathrm{M}$ to $0.54 \mu \mathrm{M}$ and averaged $0.12 \pm 0.12 \mu \mathrm{M}$ and $0.09 \pm 0.07 \mu \mathrm{M}$ in 2010 and 2011, respectively. POP concentrations ranged from $<0.07 \mu \mathrm{M}$ to $0.95 \mu \mathrm{M}$ and averaged $0.10 \pm 0.12 \mu \mathrm{M}$ and $0.07 \pm 0.08 \mu \mathrm{M}$ in 2010 and 2011. Particulate $\mathrm{P}$ concentrations were relatively stable with increasing depth. PIP concentrations in the mid-waters averaged $0.12 \pm 0.14 \mu \mathrm{M}$ and $0.08 \pm 0.11 \mu \mathrm{M}$ in 2010 and 2011 and POP concentrations averaged $0.11 \pm 0.14 \mu \mathrm{M}$ to $0.07 \pm 0.10 \mu \mathrm{M}$. Bottom waters had similar trends (PIP, $0.14 \pm 0.13 \mu \mathrm{M}$ to $0.14 \pm 0.12 \mu \mathrm{M}$; POP, $0.10 \pm 0.09 \mu \mathrm{M}$ to $0.11 \pm 0.14 \mu \mathrm{M}$ in 2010 and 2011 respectively).

Though low throughout the Chukchi Sea, TPP concentrations were always significantly higher in offshore waters relative to both ACC and inshore waters during both years, averaging $0.24 \pm 0.26 \mu \mathrm{M}$ and $0.17 \pm 0.19 \mu \mathrm{M}(\mathrm{p} 2010$ and $2011 \mathrm{ACC}<0.001$, $\mathrm{p} 2010$ inshore $=0.024, \mathrm{p} 2011$ inshore $<0.001)$ versus average ACC concentrations of 0.15 $\pm 0.08 \mu \mathrm{M}$ during both 2010 and 2011 , and inshore values of $0.19 \pm 0.16 \mu \mathrm{M}$ in 2010 and $0.12 \pm 0.05 \mu \mathrm{M}$ in 2011. Offshore and inshore waters experienced significant declines in particulate $\mathrm{P}$ concentrations relative to $2010\left(\mathrm{p}_{\text {offshore }}<0.001\right.$, and $\left.\mathrm{p}_{\text {inshore }}=0.005\right)$.

Higher offshore particulate $\mathrm{P}$ concentrations were associated with significant increases in chlorophyll a, which averaged 5.66 $\pm 9.27 \mu \mathrm{g}$ L-1 and 3.28 $\pm 0.63 \mu \mathrm{g}$ L-1 respectively (p $<0.001)$. TPP concentrations in offshore waters were almost evenly divided between POP and PIP concentrations (Figure 3.1). ACC and inshore waters contained 
significantly lower PIP and POP concentrations (ACC, PIP $=0.09 \pm 0.06 \mu \mathrm{M}, 0.10 \pm$ $0.05 \mu \mathrm{M}$ during 2010 and 2011; inshore PIP $=0.09 \pm 0.09 \mu \mathrm{M}$ in 2010 and below detection in 2011; ACC, POP = averaged below detection during both years; inshore POP $=0.09 \pm 0.10$ in 2010 and below detection in 2011) and had little to no interannual variability.

Unlike the dissolved P pool, the particulate P pools entering the Chukchi Sea decreased significantly from 2010 to 2011, however the particulate P exiting via Barrow Canyon Center remained relatively unchanged. During 2010 TPP declined 57\%, decreasing from an average of $0.30 \pm 0.20 \mu \mathrm{M}$ within the Bering Strait to $0.13 \pm 0.08 \mu \mathrm{M}$ within Barrow Canyon Center $(\mathrm{p}<0.001)$. This significant reduction was present in both the inorganic and organic phases with PIP falling $58 \%$ to $0.08 \pm 0.05 \mu \mathrm{M}(\mathrm{p}<0.001)$ and POP falling $45 \%$ to below detection limits $(\mathrm{p}=0.015)$. There was little annual difference present within Barrow Canyon center, however Bering Strait decreased by over half within each of the particulate pools ( $<<0.001)$ from 2010 to 2011 .

\subsection{Water Column Total P Speciation}

Between 2010 and 2011 cruises, the water column experienced no significant changes in the regional average total phosphorus (TP) concentration, yet nearly all of the particulate and dissolved components of the P pool varied significantly $(\mathrm{p}<0.001)$ between years, with the exception of DOP. On average, TP was comprised of $54 \pm 17 \%$ SRP, $34 \pm 16 \%$ DOP, $7 \pm 6 \%$ PIP and $5 \pm 6 \%$ POP. Some transects remained relatively constant in their TP concentrations and composition, while others were highly variable (data not shown). For example, during 2010, the highest mixed layer TP concentrations were measured in Central Channel, averaging $2.16 \pm 0.76 \mu \mathrm{M}$, with the DOP fraction 
dominating (44 $\pm 14 \%$ ), whereas the mixed layer within Barrow Canyon Center had the lowest TP concentrations $(1.21 \pm 0.51 \mu \mathrm{M})$ and was almost equally split between SRP and DOP. In 2011, the highest mixed layer TP concentrations were measured in Chukchi Slope West $(2.05 \pm 0.75 \mu \mathrm{M})$ and the lowest concentrations were found East of Barrow $(1.23 \pm 0.41 \mu \mathrm{M}) . \mathrm{SRP}$ was the dominant component of both transects, $61 \pm 15 \%$ and 69 $\pm 15 \%$ respectively. There were no trends with increasing latitude.

Within the water column, a significant decline in mixed layer TP was observed, decreasing from $1.35 \pm 0.55 \mu \mathrm{M}$ in 2010 to $1.19 \pm 0.36 \mu \mathrm{M}$ in $2011(\mathrm{p}=0.003)$. In contrast the mid-waters had small, but significant increases in TP from $1.52 \pm 0.63 \mu \mathrm{M}$ in 2010 to $1.65 \pm 0.68 \mu \mathrm{M}$ in $2011(\mathrm{p}=0.046)$. The bottom waters did not experience any annual change between 2010 and 2011 , averaging $1.87 \pm 0.64 \mu \mathrm{M}$.

During both cruise years, offshore TP concentrations were significantly higher than ACC waters $1.54 \pm 0.64 \mu \mathrm{M}$ versus $1.24 \pm 0.42 \mu \mathrm{M}$ in $2010(\mathrm{p}<0.001)$ and $1.58 \pm$ $0.67 \mu \mathrm{M}$ versus $1.27 \pm 0.32 \mu \mathrm{M}$ in $2011(\mathrm{p}<0.001)$. During 2010 , inshore water concentrations fell between offshore and ACC waters to $1.46 \pm 0.51 \mu \mathrm{M}$. In 2011 inshore waters declined even further, down to $1.12 \pm 0.16 \mu \mathrm{M}$. The most prevalent $\mathrm{P}$ pool within inshore and ACC waters was the dissolved phase at $88 \pm 5 \%$, with similar distributions between inorganic and organic pool and no significant changes with year. Offshore waters consisted of a significantly different $\mathrm{P}$ pool as these waters were dominated mainly by SRP $(49 \pm 17 \%$ in 2010 and $59 \pm 17 \%$ in 2011). As waters made their way through the Chukchi from Bering Strait to Barrow Canyon Center, little change in the total $\mathrm{P}$ concentration occurred due to the dominance of the dissolved $\mathrm{P}$ pool during both cruise years. 


\subsection{Water Column Elemental Stoichiometry}

In order to place $\mathrm{P}$ pool concentrations and distributions in perspective, dissolved and particulate $\mathrm{P}$ concentrations were compared to dissolved inorganic nitrogen $(\mathrm{DIN}=$ NO3- + NO2- + NH4+) POC, and PN with depth (mixed layer, mid waters, bottom waters) and with water mass (inshore, ACC, offshore) (Figure 3.2-3.5). In the mixed layer, SRP concentrations were plentiful with respect to DIN in all inshore and ACC waters (Figure 3.2). Offshore waters had bifurcated trends, with one data set characterized by high SRP concentrations and below detection DIN, and a second data set characterized by a DIN:SRP ratio of $5\left(\mathrm{R}^{2}=0.29\right)$ (when all DIN data $<2 \mu \mathrm{M}$ are not considered). Moving deeper into the water column to the middle and deep waters, nitrogen depletion was reduced, with a DIN:SRP ratio of 10:1 $\left(\mathrm{R}^{2}=0.56\right)$ and $10: 1\left(\mathrm{R}^{2}=\right.$ 0.52) respectively. In 2011, Atlantic waters were also sampled and were characterized by lower DIN:SRP ratios of 1.6:1 $\left(\mathrm{R}^{2}=0.31\right)$. There were no significant differences between sample years with regards to the DIN:SRP ratio $(p>0.05)$.

In order to understand particulate stoichiometry, POC and PN concentrations versus both POP and TPP were examined (Figure $3.3 \& 3.4$ ). While TPP is typically assumed to be derived solely from biological activity in the open ocean, coastal waters are more complex due to terrigenous fluxes from the near shore that may add non-living and mineral P (PIP) to the system (Benitez-Nelson, 2000). POP concentrations also underestimate biologically derived inorganic $\mathrm{P}$ components, such as polyphosphate (Hupfer et al. 2008). In contrast to the dissolved phase, particulate elemental ratios varied not only with depth, but with year as well, and had similar trends across all water masses, albeit data were limited. 
Within the mixed layer, $69 \%$ of the PN concentration can be explained by changes in POC with a POC: PN ratio of 8:1 (Figure 3.5). With depth, this relationship moved closer to canonical Redfield et al. (1958) ratios of 7:1, with the correlation increasing in strength to $81 \%$ and $75 \%$ within the mid and bottom waters respectively. The POC:POP (TPP) ratio was higher than the Redfield ratio at 180:1 $\left(\mathrm{R}^{2}=0.58\right)$, however when the inorganic fraction is included the ratio fell to 104:1 and the relationship was reduced in strength $\left(\mathrm{R}^{2}=0.52\right)$ (Figure 3.3). A similar decline was observed for PN to particulate $\mathrm{P}$ ratios as well, with a PN: POP ratio of $13: 1\left(\mathrm{R}^{2}=0.30\right)$ and PN:TPP ratio of 10:1 ( $\left.\mathrm{R}^{2}=0.46\right)$ (Figure 3.4). Samples collected during under ice blooms in 2010 and 2011 were different from the bulk dataset and from one another, with significantly higher POC: PN: POP (TPP) ratios of 898:52:1 (274:16:1) in 2010 and below detection POP (784:124:1) in 2011 suggesting rapid biological uptake and production of vey labile organic matter.

Middle waters were characterized by lower POC:POP (TPP), and POC: PN but higher PN: POP (TPP) ratios than those measured in the surface and were consistent with preferential remineralization of $\mathrm{P}$ relative to $\mathrm{N}$ with increasing depth, even in this shallow sea (Figure 3.3-3.5). There were no significant differences between the various water masses or with year. Deeper waters were characterized by significantly different elemental ratios than those found in the mixed layer and in middle waters as ratios decline and relationship strength was reduced.

DIN and SRP concentrations experience minute changes between the time they enter the Chukchi Sea via the Bering Strait and exit via Barrow Canyon Center. Furthermore, there were no significant dissolved nutrient patterns. In contrast, although 
the particulate pool was only a small component of the total P pool, elemental ratios declined from the Bering Strait (POC:PN:TPP $={ }_{2010} 78: 11: 1,{ }_{2011} 65: 12: 1$ ) to Barrow Canyon (201047:6:1, 201113:2:1) (Table 1). The declining relationship both from 2010 to 2011 and from Bering Strait to Barrow Canyon Center, was driven by the large scale reduction in POC and PN concentrations. While POP and TPP concentrations also declined, this decrease was not to the same extent, thus decoupling the relationships between POC:POP (TPP) and PN:POP (TPP).

\subsection{Sea Ice}

In order to understand the potential role of sea ice melt on the underlying water column, P inventories were determined within the entirety of each core compared to the nutrient inventories measured in the corresponding mixed layer of the sampled station. Mixed layer inventories were determined using a uniform depth of $5 \mathrm{~m}$, as the average mixed layer below the ice sheets was $5 \pm 1 \mathrm{~m}$ in 2010 and $5 \pm 4 \mathrm{~m}$ in 2011 . Sea Ice SRP and DOP concentrations were only measured in 2011 averaged $6.23 \pm 0.80 \mu \mathrm{mol} \mathrm{m}-2$ and $9.97 \pm 4.42 \mu \mathrm{mol} \mathrm{m}-2$ respectively, and showed no clear trends within each ice core (Figure 3.6). While average TDP and SRP concentrations were significantly lower than underlying mixed layer waters $(\mathrm{p}<0.05)$, average DOP concentrations were similar. TPP and PIP concentrations were measured in both 2010 and 2011 and were significantly different between years (Figure 3.7). In 2010, particulate P concentrations averaged $12.35 \pm 12.93 \mu \mathrm{mol} \mathrm{m}-2$ and $6.14 \pm 7.86 \mu \mathrm{mol} \mathrm{m}-2$, while in 2011 , concentrations were over 10 times lower, averaging $0.94 \pm 0.47 \mu \mathrm{mol} \mathrm{m}-2$ and $0.60 \pm 0.23 \mu \mathrm{mol} \mathrm{m}-2$. These differences are likely due to sampling location (offshore in 2011, inshore in 2010) although temporal differences cannot be dismissed. 
If all of the first year ice measured were to melt, TP concentrations in the upper 5 meters would decline to $28.45 \pm 5.91 \mu \mathrm{mol} \mathrm{m}-2$ (28\%). Average DOP would decline the least, dropping by $0.28 \mu \mathrm{mol} \mathrm{m}-2$ or $3 \%$ to $10.24 \pm 0.99 \mu \mathrm{mol} \mathrm{m}-2$. Thus much of the changes that would occur in the TDP pool are driven by dilution of SRP, which would decline by $35 \%$ to $13.53 \pm 3.68 \mu \mathrm{mol} \mathrm{m}-2$. In the particulate phases both PIP and POP would decline by nearly $50 \%$, to $2.49 \pm 1.04 \mu \mathrm{mol} \mathrm{m}-2$ and $2.20 \pm 1.75 \mu \mathrm{mol} \mathrm{m}-2$, respectively. DIN concentrations were much more variable and ice melt would result in an overall decrease of $6 \%$ to an average of $8.66 \pm 6.57 \mu \mathrm{mol} \mathrm{m}-2$.

Nutrient ratios within the sea ice were analyzed by year and ice type (i.e. sediment-laden vs. clean) (Figure 3.8). Sediment-laden sea ice had substantially higher PC and PN concentrations and higher C:N:P ratios (456:31:1) compared to those of both 2010 clean ice (34:2:1) and 2011 clean ice (143:27:1). While all sea ice collected in 2011 had considerably lower nutrient concentrations, elemental ratios were much closer to canonical Redfield et al. (1958) ratios of 106:16:1. 
Table 3.1: Average concentrations ( \pm standard deviation) alongside nutrient ratios within the Bering Strait $\left(\mathrm{n}_{2010}=28, \mathrm{n}_{2011}=12\right)$ and Barrow Canyon Center $\left(\mathrm{n}_{2010}=27, \mathrm{n}_{2011}=24\right)$ transects. Bold letter indicates significant annual differences within sites $(<0.05)$, while underlined text indicates interannual differences between sites $(<0.05)$.

\begin{tabular}{|c|c|c|c|c|c|c|c|c|c|c|c|c|c|c|}
\hline Transect & $\begin{array}{l}\text { Total P } \\
(\mu \mathrm{M})\end{array}$ & $\begin{array}{l}\text { TDP } \\
(\mu \mathrm{M})\end{array}$ & $\begin{array}{c}\text { SRP } \\
(\mu \mathrm{M})\end{array}$ & $\begin{array}{l}\text { DOP } \\
(\mu \mathrm{M})\end{array}$ & $\begin{array}{l}\text { DIN } \\
(\mu M)\end{array}$ & $\begin{array}{l}\text { TPP } \\
(\mu \mathrm{M})\end{array}$ & $\begin{array}{c}\text { PIP } \\
(\mu \mathrm{M})\end{array}$ & $\begin{array}{l}\text { POP } \\
(\mu M)\end{array}$ & $\begin{array}{l}\text { POC } \\
\text { ( } \mu M)\end{array}$ & $\begin{array}{l}\text { PN } \\
(\mu \mathrm{M})\end{array}$ & POC:TPP & POC:POP & PN:TPP & PN:POP \\
\hline $\begin{array}{c}2011 \\
\text { Barrow } \\
\text { Canyon } \\
\text { Center }\end{array}$ & $1.32 \pm 0.49$ & $1.18 \pm 0.45$ & $0.70 \pm 0.31$ & $0.54 \pm 0.59$ & $\underline{2.62 \pm 4.45}$ & $0.14 \pm 0.11$ & $0.08 \pm 0.04$ & $0.07 \pm 0.10$ & $\underline{8.27 \pm 4.13}$ & $\underline{1.18 \pm 0.65}$ & $\begin{array}{c}13: 1 \\
R^{2}=0.12\end{array}$ & $\begin{array}{c}16: 1 \\
R^{2}=0.16\end{array}$ & $\begin{array}{c}2: 1 \\
R^{2}=0.17\end{array}$ & $\begin{array}{c}2: 1 \\
R^{2}=0.10\end{array}$ \\
\hline
\end{tabular}



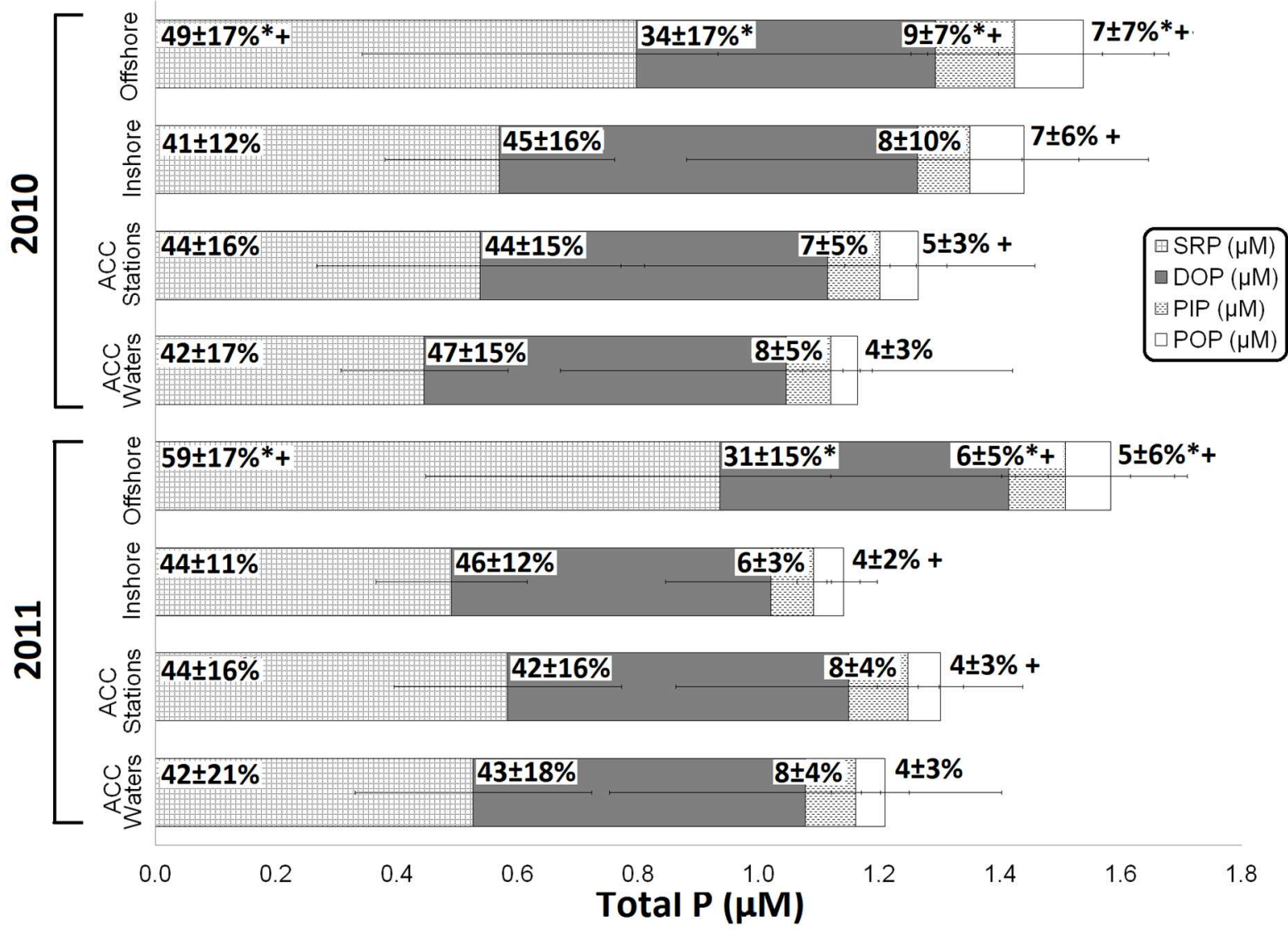

Figure 3.1: Average Total P concentration and speciation with depth in offshore waters, ACC waters and Stations, and Inshore waters, during both 2010 and 2011 cruises. Percent compositions provided, * represents significant shifts in percent composition of the total P pool, while + represents concentration disparity. Error bars indicate standard deviation. 

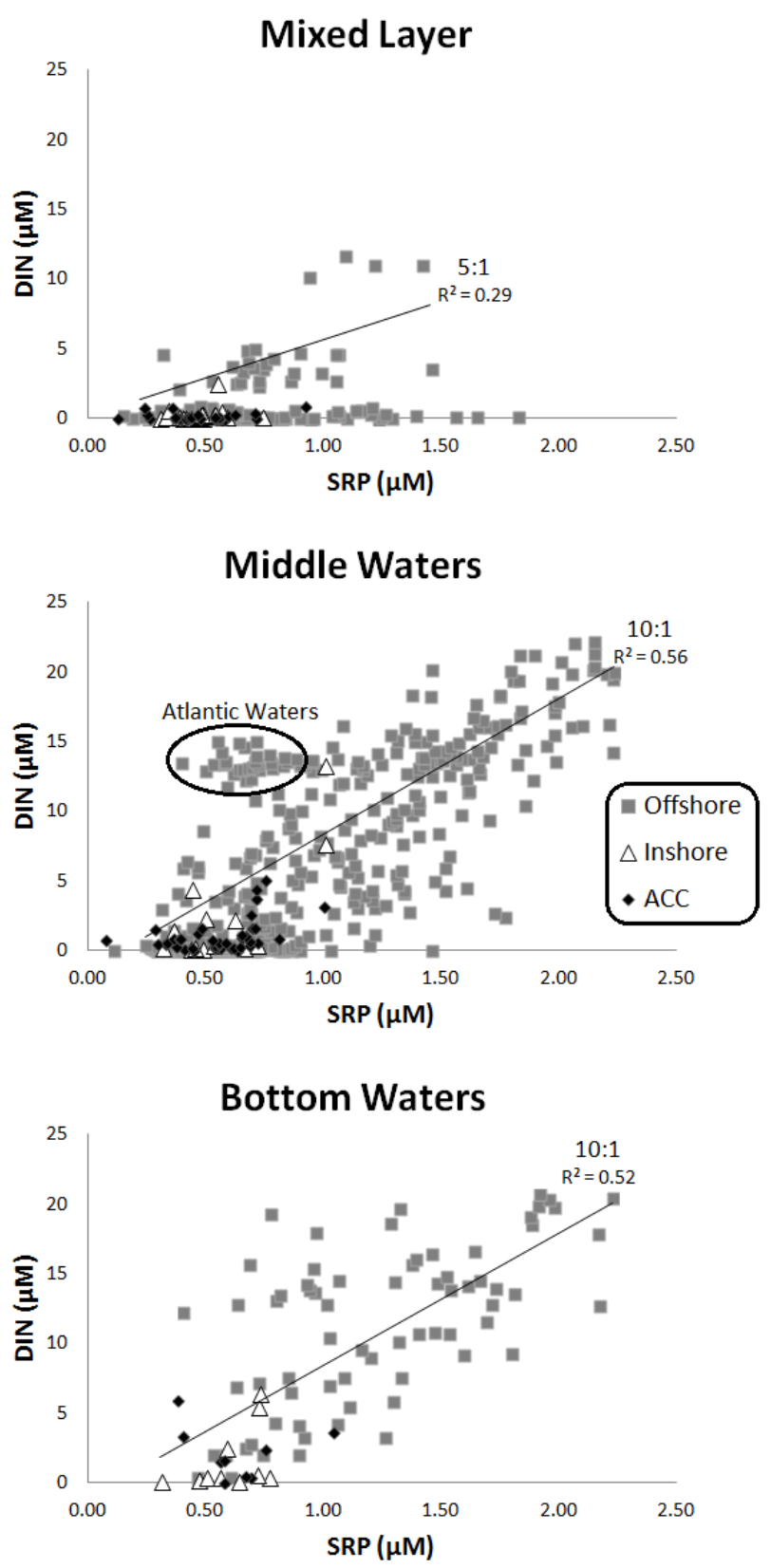

Figure 3.2: DIN:SRP $(\mu \mathrm{M})$ within the mixed layer $\left(\mathrm{R}^{2}=\right.$ $0.43)$, middle waters $\left(\mathrm{R}^{2}=0.60\right.$ excluding Atlantic waters), and bottom waters $\left(\mathrm{R}^{2}=0.42\right)$ during both 2010 and 2011 cruises, with Offshore (squares), ACC waters (diamonds), and Inshore (triangles) plotted separately for comparison. Linear relationship includes all stations from each of the three regions, but excludes any samples with DIN below 2 $\mu \mathrm{M}$. All p-values $<0.001$ 

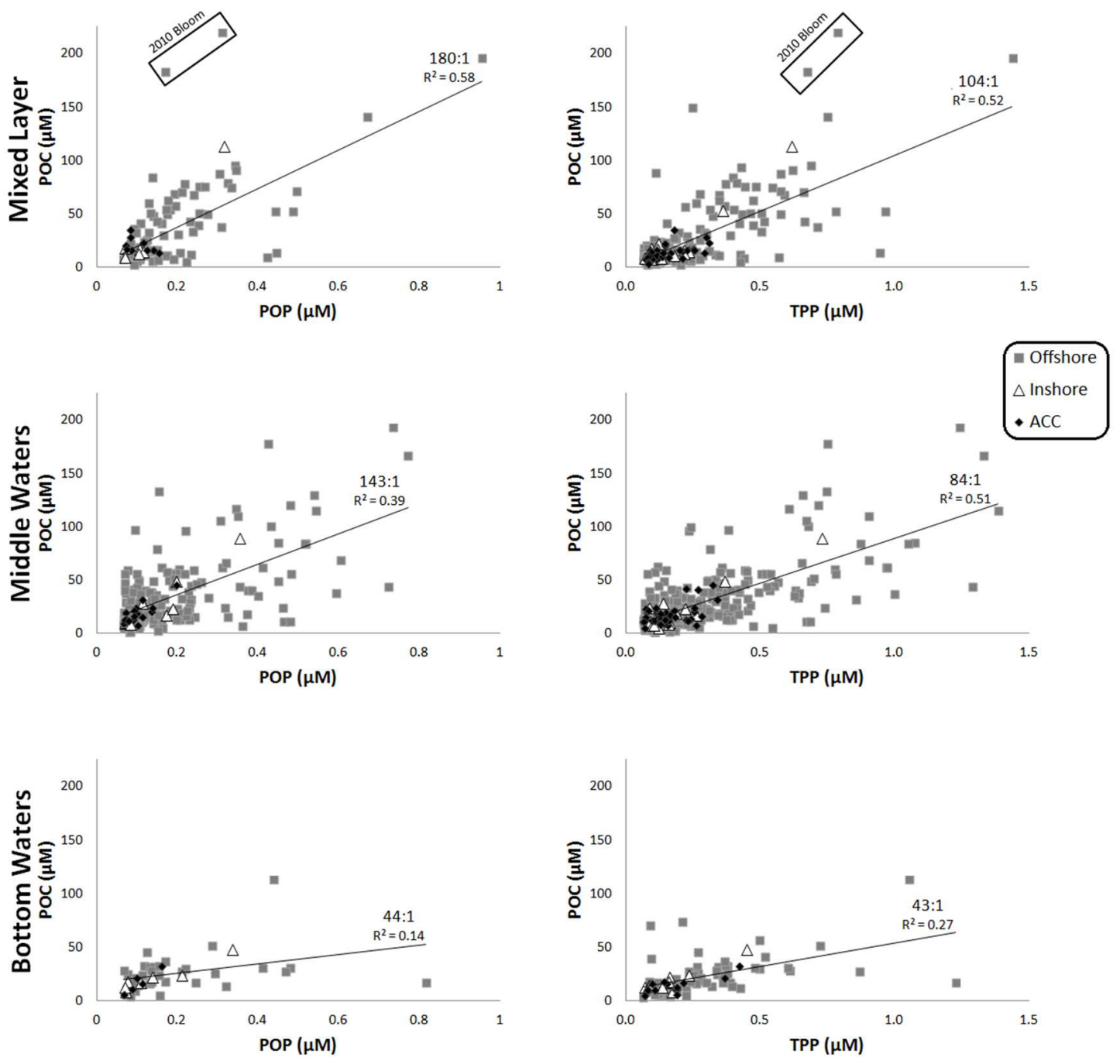

Figure 3.3: POC: POP within mixed layer $\left(\mathrm{R}^{2}=0.42\right)$, middle waters $\left(\mathrm{R}^{2}=0.48\right)$, and bottom waters $\left(\mathrm{R}^{2}=0.13\right)$, as well as PN:TPP within layer $\left(\mathrm{R}^{2}=0.54\right)$, middle waters $\left(\mathrm{R}^{2}=0.59\right)$, and bottom waters $\left(\mathrm{R}^{2}=0.30\right)$, during both 2010 and 2011 cruises. Offshore (squares), ACC waters (diamonds), and Inshore (triangles) plotted separately for comparison. All p-values $<0.001$ 

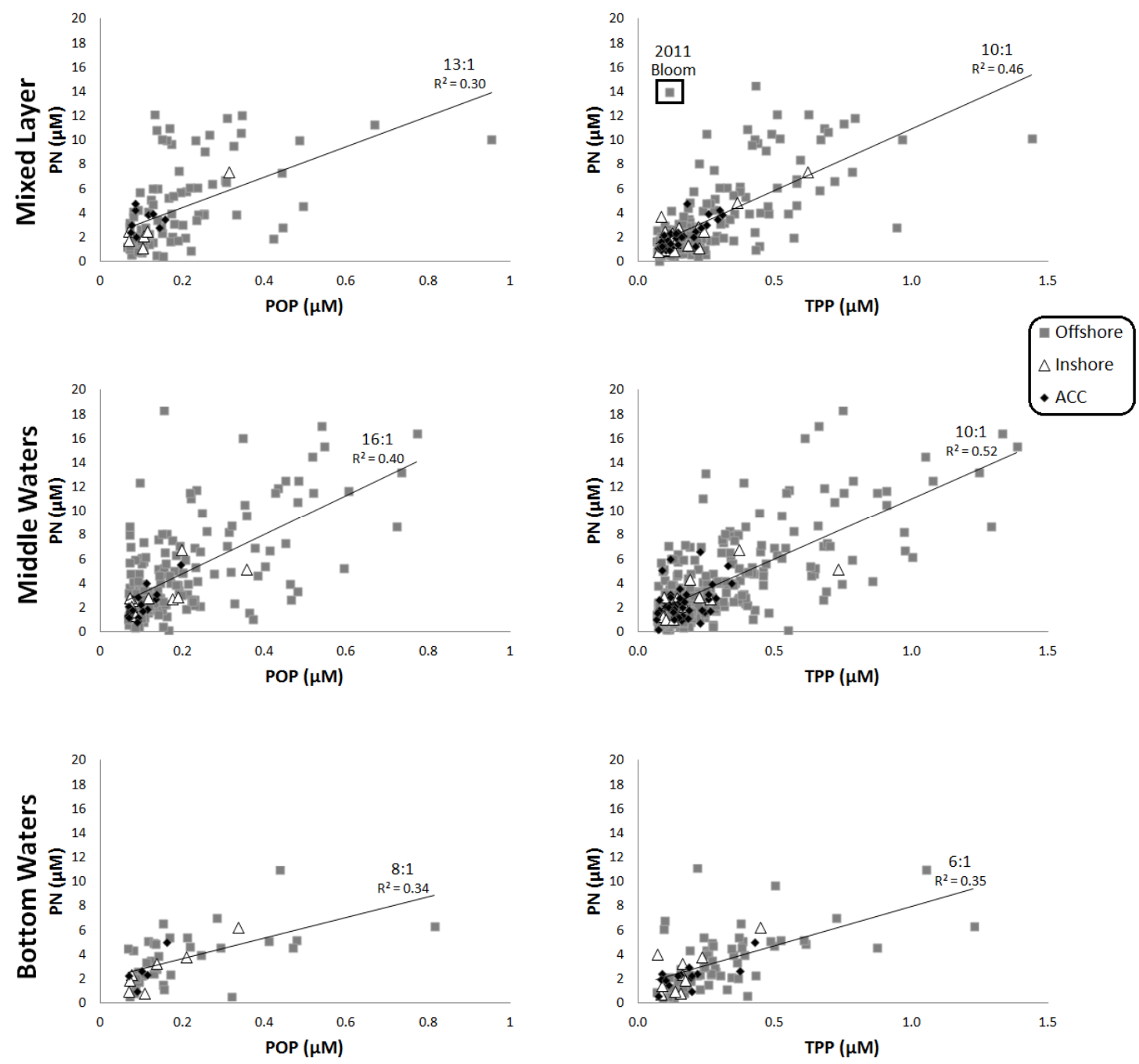

Figure 3.4: PN: POP within mixed layer $\left(\mathrm{R}^{2}=0.32\right)$, middle waters $\left(\mathrm{R}^{2}=0.46\right)$, and bottom waters $\left(\mathrm{R}^{2}=0.17\right)$, as well as PN:TPP within layer $\left(\mathrm{R}^{2}=0.52\right)$, middle waters $\left(\mathrm{R}^{2}=0.59\right)$, and bottom waters $\left(\mathrm{R}^{2}=0.37\right)$, during both 2010 and 2011 cruises. Offshore (squares), ACC waters (diamonds), and Inshore (triangles) plotted separately for comparison. All p-values $<0.001$ 

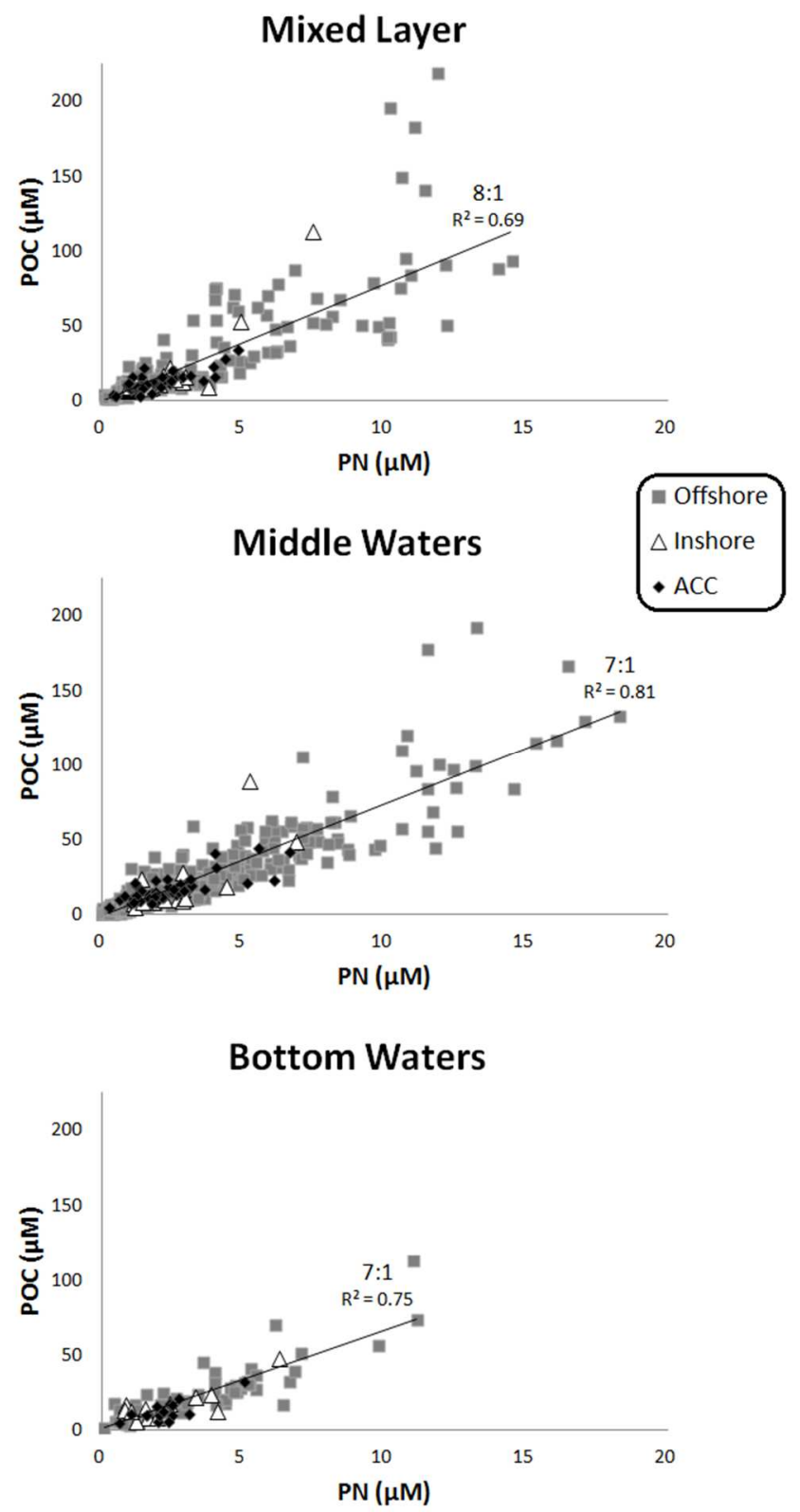

Figure 3.5: POC: $\mathrm{PN}$ within mixed layer $\left(\mathrm{R}^{2}=0.67\right)$, middle waters $\left(\mathrm{R}^{2}=0.81\right)$, and bottom waters $\left(\mathrm{R}^{2}=0.72\right)$. Offshore (squares), ACC waters (diamonds), and Inshore (triangles) plotted separately for comparison. All p-values $<0.001$ 


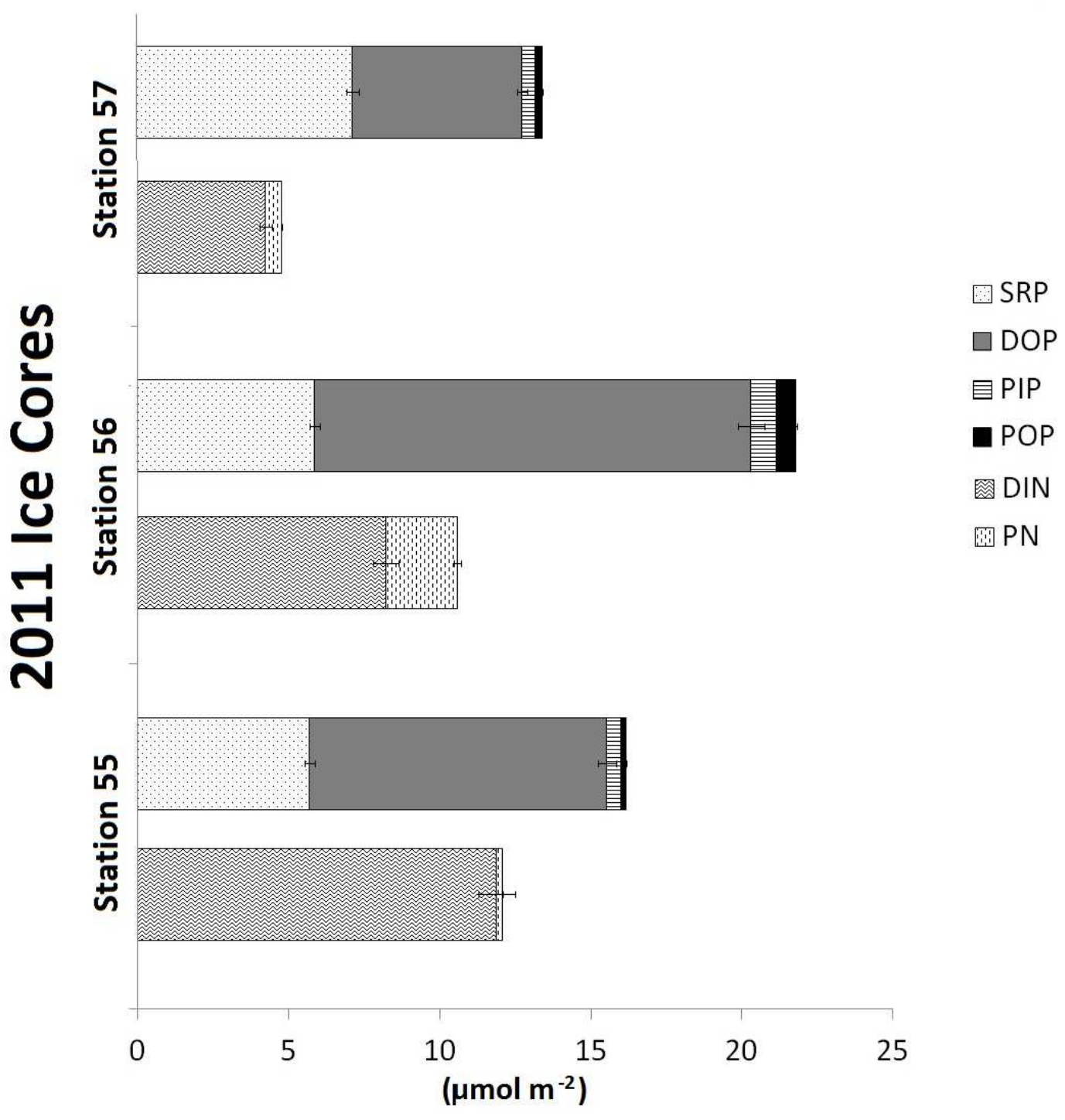

Figure 3.6: Total $\mathrm{P}$ and TN $\left(\mu \mathrm{mol} \mathrm{m} \mathrm{m}^{-2}\right)$ inventories normalized to area for the three ice core stations sampled for P during the 2011 cruise, error bars represent analytical error. 


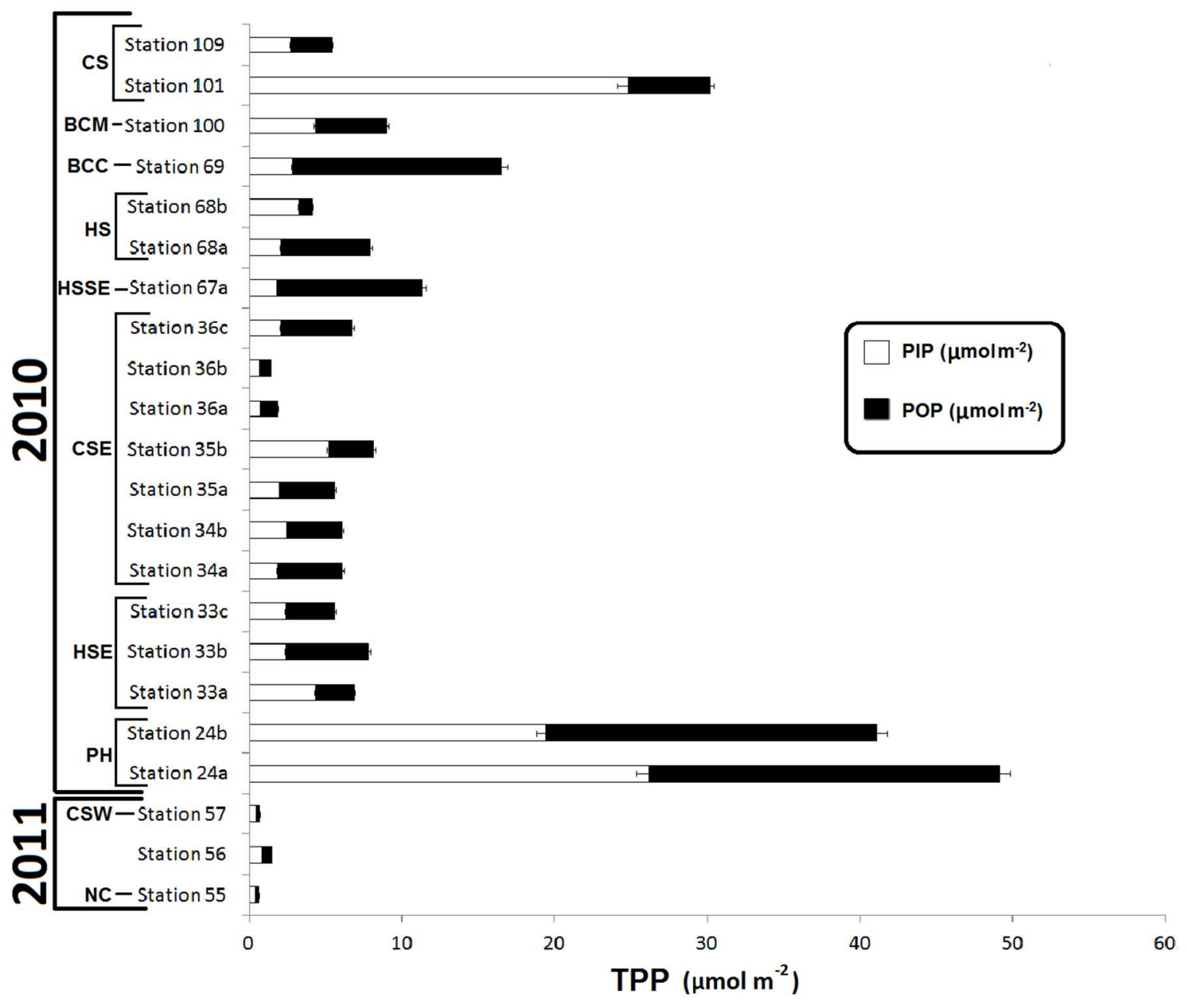

Figure 3.7: Total particulate $\mathrm{P}\left(\mu \mathrm{mol} \mathrm{m} \mathrm{m}^{-2}\right)$ inventories normalized to area for all ice cores sampled for $P$ at all stations during both 2010 and 2011 cruises. 

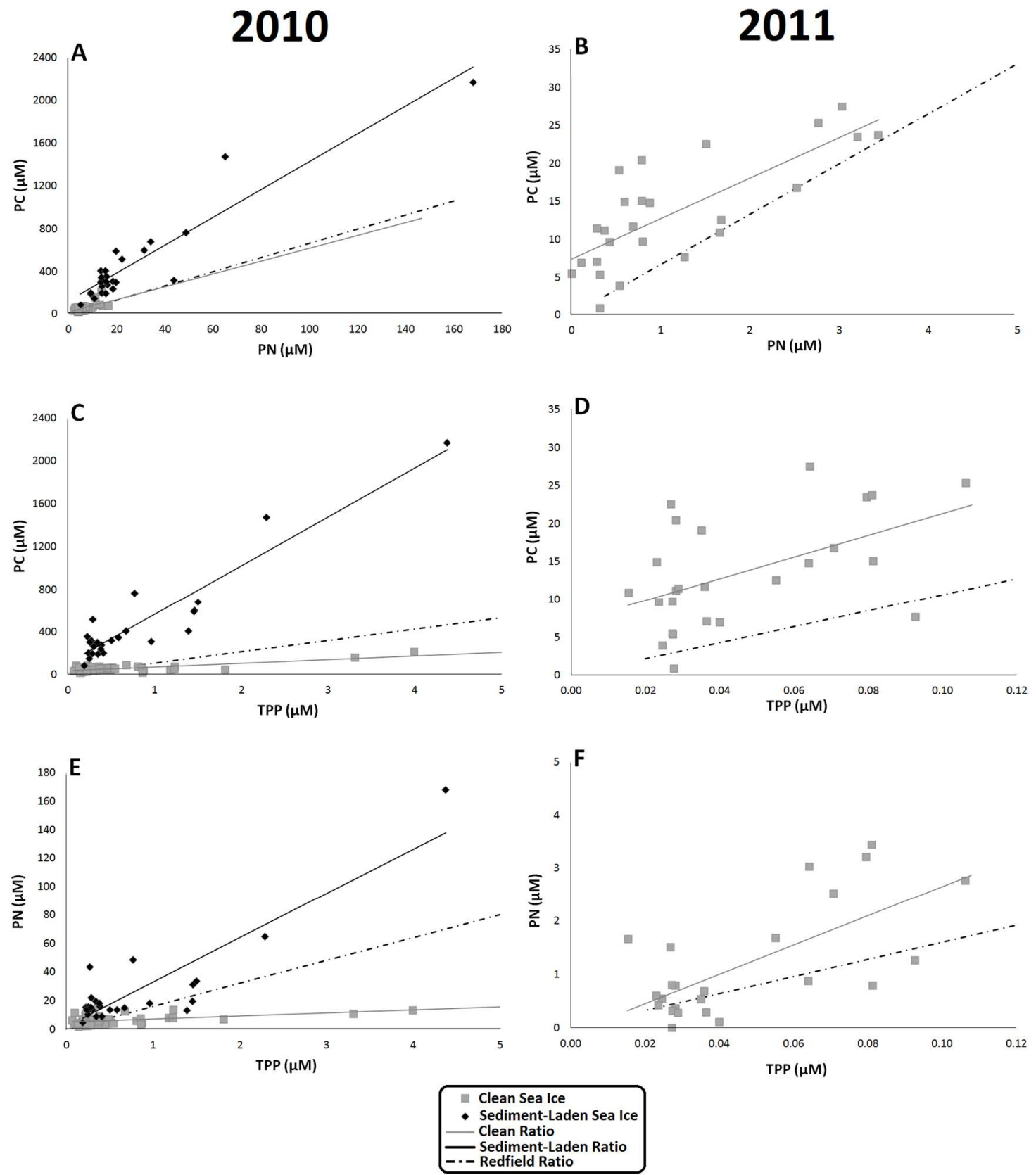

Figure 3.8: Particulate $C: N: P$ regression plots within 2010 sediment laden sea ice $(C: N$ $\left.\mathrm{R}^{2}=; \mathrm{C}: \mathrm{P} \mathrm{R}^{2}=; \mathrm{N}: \mathrm{P} \mathrm{R}^{2}=\right), 2010$ clean ice $\left(\mathrm{C}: \mathrm{N} \mathrm{R}^{2}=; \mathrm{C}: \mathrm{P} \mathrm{R}^{2}=; \mathrm{N}: \mathrm{P} \mathrm{R}^{2}=\right)$, and 2011 clean ice $\left(C: \mathrm{N} \mathrm{R}^{2}=0.64 ; \mathrm{C}: \mathrm{P} \mathrm{R}^{2}=0.34 ; \mathrm{N}: \mathrm{P} \mathrm{R}^{2}=0.55\right)$. All p-values $<0.00$ 


\section{CHAPTER 4}

\section{DISCUSSION}

As P makes its way through the Chukchi Sea and into the Arctic Ocean, P concentrations and composition are influenced by a variety of processes that include river runoff, bottom resuspension, biological activity, and sea ice melt. Most of these processes were evident during the 2010 and 2011 sampling periods, with the exception of resuspension, causing significant regional variability.

4.1 Riverine Inputs and Bottom Resuspension

Given the coastal nature of our sampling, riverine inputs may potentially supply $\mathrm{P}$ into the Chukchi Sea (e.g., Galloway et al. 1996, Ruttenberg 2003), particularly in Kotzebue Sound. Previous studies however, show that both the Yukon and Mackenzie rivers are relatively low in P (average fluxes of 1.9 x 109 and 1.5 x 109 g y-1 P) particularly relative to $\mathrm{N}$ (average fluxes of $19-24$ x 109 and $12.5 \times 24 * 109 \mathrm{~g}$ y-1 N) thus resulting in provided N:P ratios of about 10-13 and 8-16 respectively (Gordeev et al. 1996, Holmes et al. 2012, Le Fouest et al. 2013). This suggests that the smaller rivers feeding directly into the eastern Chukchi Sea (e.g., Noatak, Selawik, and Kobuk Rivers) are likely lower in $\mathrm{P}$ as well. Indeed, average dissolved $\mathrm{P}$ concentrations inshore of the ACC, are consistently lower than offshore waters and there was no difference in inshore P concentrations between 2010 and 2011(Figure 3.1). While an increase in suspended particulate $\mathrm{P}$ is also possible, there was no clear evidence of high particulate $\mathrm{P}$ inshore relative to offshore, suggesting that if particulate $\mathrm{P}$ was sourced by rivers, it was rapidly 
removed from the system (Ruttenberg 2003, Benitez-Nelson 2000). Zhang et al. (2010) examined sediment core nutrient concentrations and ratios inshore (near Icy Cape transect), and found TN:TP to be 1.6, while total $\mathrm{N}$ to total organic $\mathrm{P}$ was much higher at 14.2. Their study highlights the dominance of terrestrial $P$ within this shallow basin Bottom resuspension is another potential source of $\mathrm{P}$ to marine systems, particularly in shallow seas. However there was little evidence that bottom resuspension occurred during our summer cruises. On rare occurrence (fewer than $21 \%$ of the bottom water sampled), bottom water particulate $\mathrm{P}$ concentrations were elevated relative to that measured in the overlying mid water and mixed layer. Increases in bottom water dissolved P concentrations may occur due to resuspension or remineralization of P. Souza et al. (2014b) found a significant efflux of P from sediments at stations located within the inshore and offshore regions in this study area, but found uptake of phosphate via sediments located within the ACC.

While increases in dissolved P occurred with increasing depth in the Chukchi Sea, our data did not allow us to differentiate whether the increase was due to regeneration of $\mathrm{P}$ from sediments or remineralization of $\mathrm{P}$ from sinking material from above. As mentioned previously, sediment cores taken close in proximity to our sampling region are characterized by $\mathrm{N}: \mathrm{P}$ ratios of 14.2, considerably higher than the average $\mathrm{N}: \mathrm{P}$ ratio of 6 measured in bottom waters in this study (Figure 3.4). This suggests that sediment resuspension was not a dominant source of $\mathrm{P}$ to the water column during our study. Rather, the decline in N:P ratios in bottom waters was likely due to preferential removal of nitrogen via denitrification (see Section 4.2). 


\subsection{Biology}

Phosphorus plays a key role in a number of biochemical reactions within marine systems by influencing biological production as well as community composition and food web structure (Karl 2014). In order to understand the potential role of $\mathrm{P}$ in the Chukchi Sea, however, we need to consider both $\mathrm{N}$ and $\mathrm{C}$ as well. For decades, the concept that all marine phytoplankton have a fixed "Redfield" ratio of $\mathrm{C}, \mathrm{N}$, to $\mathrm{P}$ has been the foundation of numerous studies that examine carbon and nutrient biogeochemistry in marine systems. In essence, any deviation in the elemental ratios of $\mathrm{C}, \mathrm{N}$, and $\mathrm{P}$ from canonical Redfield ratios is often used to determine nutrient limitation or stress (Redfield 1958, Tyrrell 1999). However, the relationships between these elements are often decoupled, particularly in nearshore regimes, owing to changes in nutrient source, food web dynamics, and physical forcing (Karl et al. 1997, Weber and Deutsch 2010, Martin et al. 2014).

During both the 2010 and 2011 ICESCAPE cruises within the Chukchi Sea, dissolved and particulate $\mathrm{N}$ and $\mathrm{P}$ concentrations were poorly correlated relative to POC and PN (Figure 3.2-3.5). In surface waters, dissolved $\mathrm{N}$ concentrations in the mixed layer for most of our study region were below detection, suggesting strong $\mathrm{N}$ limitation, consistent with other work (Cota et al. 1996, Mills et al. 2015). Only in offshore waters and with increasing depth do dissolved nutrient relationships begin to emerge (Figure 3.2). When DIN is exhausted in surface waters, SRP concentrations remain high, averaging $1.30 \mu \mathrm{M}$, with an $\mathrm{N}: \mathrm{P}$ ratio $<2$. As a result, there was a significant source of dissolved P entering the Arctic Ocean within the surface waters alone and is a major source of "excess" P relative to $\mathrm{N}$ within the Arctic Ocean. Indeed, recent studies 
suggest that the Arctic Ocean as a whole is a net exporter of phosphate $(\sim 1.0 \pm 0.3 \mathrm{kmol}$ $\mathrm{s}-1$, net \pm 1 std error) to the North Atlantic (Torres-Valdés et al. 2013). In fact, this is likely an underestimate of $\mathrm{P}$, due to the high DOP concentrations and thus, high DOP export to the Arctic Ocean. Such low dissolved N:P ratios within the Arctic Ocean provide an ideal environment for nitrogen fixation and are likely a major driving factor in the high nitrogen fixation rates observed downstream within the northern Atlantic Ocean (Yamamoto-Kawai et al. 2006).

As one moves deeper into the water column SRP and DIN relationships begin to emerge due to the remineralization of sinking organic matter. DIN:SRP ratios in offshore mixed layer and mid waters throughout the Chukchi Sea ranged from 7-9.1 consistent with biological activity associated with low N:P sinking material (see below, Martiny et al. 2013), or removal of DIN via denitrification (Mills et al. 2015). Similar ratios were presented in Souza et al.'s (2014) study of N:P within the surface and bottom waters throughout the Chukchi Sea. Their findings indicate dissolved inorganic surface water $\mathrm{N}: \mathrm{P}$ ratios vary between $0.4-3.5$ and deep water N:P ratios range from $6-15$.

Particulate N:P ratios were also quite variable throughout the Chukchi Sea (Figure 3.4). It is now recognized that various groups of marine phytoplankton have $\mathrm{N}: \mathrm{P}$ ratios that span a factor of 5 or more (Geider and La Roche 2002, Bertilsson et al. 2003, Ho et al. 2003, Martiny et al. 2013). Most of this N:P plasticity is attributed to the ability of cyanobacteria to utilize nitrogen from the atmosphere for their nutritional $\mathrm{N}$ needs (e.g., nitrogen fixation) as well as the bioaccumulation of inorganic and oxidized organic $\mathrm{P}$ forms that contain minimal $\mathrm{N}$ (e.g., polyphosphate or phospholipids) even during times periods when dissolved $\mathrm{P}$ concentrations are quite low $(<0.05 \mu \mathrm{M})($ Orchard et al. 2010, 
Martin et al. 2014). Recently, Martiny et al. (2013) presented a global compilation of particulate C:N:P ratios and found significantly lower ratios than traditional Redfield within the polar regions (78:13:1). These low C:N:P ratios are generally the result of high diatom abundances as they tend to utilize much more $\mathrm{P}$ relative to other phytoplankton communities (Twining et al. 2004). Therefore, lower C:N:P values were expected with the abundant diatom community present within the Chukchi Sea during the 2010-2011 sampling periods (Hill et al. 2005). Ratios may decline even further with depth due to extensive denitrification in the mid and deep waters during our study (Mills et al. 2015). Indeed, N:P ratios range from 6:1 to $16: 1$ depending on depth and the form of particulate $\mathrm{P}$ used in the ratio analysis.

\subsection{The Role of Sea Ice}

Alterations in warm Pacific water movement is likely a dominating factor in the increased sea ice melt specific to this region during 2011 (Brugler et al. 2014). As such, the 2011 ICESCAPE's cruise did not have the opportunity to sample sea ice in close proximity to land masses, and extended farther north than the 2010 cruise. This earlier ice retreat seemingly led to the increased stratification observed in 2011.

Within the sea ice there were large annual variations with 2010 ice cores experiencing particulate $\mathrm{P}$ values up to 35 times higher than that measured in 2011 sea ice (Figure 3.7). The reasoning behind this difference is unclear as it could be tied to both annual and spatial variations. In 2010, sea ice cores were collected much closer to land and were visibly more sediment laden. Although not all near shore (2010) samples were sediment laden, they still held a considerably higher amount of particulate P. The variability noted in both the dissolved and particulate $\mathrm{P}$ concentrations were as expected. 
Sea ice, particularly in the shallow Chukchi Sea, reaches the seafloor, and therefore can potentially include the benthos allowing for nutrient regeneration within the ice core (Gradinger and Ikävalko 1998). All ice is not created equal, thus resulting in considerable variability within each ice core. This patchiness is attributed to the depth at which the ice was formed (Reimnitz et al. 1992), what kind of dust/snow inputs occurred in the region (Ehn et al. 2004, Nomura et al. 2011), and when melt ponds were present or ice had thinned, and the magnitude of biological production within the ice (Arrigo 2014, Garrison et al.1986, Gradinger and Ikävalko 1998).

Variations in sea ice (i.e., sediment laden versus "clean") have large impacts on the nutrient ratios within the core, and thus, on the surrounding environment when the ice melts (Figure 3.8). In 2010, sediment laden sea ice particulate C:N:P ratios of 456:31:1 were even higher than generally found in terrestrial environments (Elser et al. 2000). This suggests that as $\mathrm{N}$ is added to the system during ice melt, the Chukhci Sea may become less nitrogen limited for a transient period. Clean sea ice present must also be considered in future implication of the nutrient pools. During the same cruise (2010) clean sea ice nutrient ratios were significantly lower (34:2:1). As such, the addition of clean sea ice melt would likely lead to the exacerbation of $\mathrm{N}$ limitation in this already $\mathrm{N}$ limited system. Due to the higher nutrient ratios (168:30:1) examined in the offshore 2011 ice cores, it is more likely that increased sea ice melt would alleviate nitrogen limitation and therefore, increase water column primary production within the Chukchi Sea.

During the ICESCAPE cruises phytoplankton blooms occurred under ice, possibly fueled by nutrient input from melting sea ice. Melnikov et al. (2002) found that when ice was sampled in spring (April, just before ice melt), SRP concentrations were 
much higher than concentrations observed in the following Fall, implying that phosphate increases in sea ice over time. However, when nutrient inputs from sea ice melt are adjusted to the volume of fresh water melted into the mixed layer, there is a significant dilution effect. The dilution is relatively small for DIN, but significant for SRP, thereby impacting the nutrient ratio. Given that Chukchi Sea blooms are likely nitrogen limited (Hameedi 1978, Arrigo et al. 2012, Mills et al. 2015), dilution does not appear to inhibit blooms from occurring; although it may impact the biological diversity, at least on a transient basis, of responding organisms as ice melt expands. 


\section{CHAPTER 5}

\section{CONCLUSION}

Due to climate change and biological abundance, studies within the Chukchi and Beaufort seas have increased throughout the years. Many of these studies have aimed to aid in scientific collections for NOAA fisheries service as a decision to open the Arctic region to commercial fisheries. However as climate continues to change and the P supply continues to shift, there could be a fundamental change in ecosystem structure within the Chukchi Sea and Arctic region. This idea is not farfetched as the much studied Bering Sea has encountered a shift from a benthic to a pelagic environment (Grebmeier 2012). With increasing stratification due to winds (Brugler et al. 2014), resuspension may be reduced in a future Arctic. DIN and SRP experience an anticipated relationship at several stations in the offshore waters, likely because other sources of $\mathrm{P}$ are added to the system, e.g., bottom water mixing, and coastal inputs are reduced. Due to the relatively small amount of $\mathrm{P}$ data collected in this region it is unknown if the decoupling has always occurred or whether it is a new or seasonal phenomenon.

The Arctic has been attributed to the increasing P concentration within the Atlantic that fuels nitrogen fixation (Yamamoto-Kawai et al. 2006). This study shows the drawdown of N:P occurs as waters travel through the Chukchi and make their way into the Arctic. This study shows that this shift of N:P is likely due to the drastic draw down of $\mathrm{N}$ rather than increasing $\mathrm{P}$ concentrations as waters make their way into the Atlantic. This shift in N:P ratios will exacerbate the already $\mathrm{N}$ limited system. With sea ice adding 
more $\mathrm{N}$ relative to $\mathrm{P}$ (though may still dilute both pools) it is possible that during the melt season $\mathrm{N}$ will become less limiting than in prior years. This shift may also cause an alteration in the phytoplankton community structure, further altering the nutrient abundances and ratios in addition to the overall ecosystem (Twining et al. 2004). 


\section{REFERENCES}

Armstrong, F.A.J., Stearns, C.R., Strickland, J.D.H., 1967. The measurement of upwelling and subsequent biological process by means of the Technicon Autoanalyzer ${ }^{\circledR}$ and associated equipment. Deep Sea Research and Oceanographic Abstracts, 14(3): 381-389.

Arnell, N.W., 2005. Implications of climate change for freshwater inflows to the Arctic Ocean. Journal of Geophysical Research: Atmospheres (1984-2012), 110(D7).

Arrigo, K.R., 2014. Sea Ice Ecosystems. Annual Review of Marine Science, 6(1): 439467.

Arrigo, K.R. et al., 2012. Massive Phytoplankton Blooms Under Arctic Sea Ice. Science, 336(6087): 1408.

Arrigo, K.R. et al., 2014. Phytoplankton blooms beneath the sea ice in the Chukchi sea. Deep Sea Research Part II: Topical Studies in Oceanography, 105(0): 1-16.

Arrigo, K.R., van Dijken, G.L., 2011. Secular trends in Arctic Ocean net primary production. Journal of Geophysical Research: Oceans (1978-2012), 116(C9).

Aspila, K.I., Agemian, H., Chau, A.S.Y., 1976. A semi-automated method for the determination of inorganic, organic and total phosphate in sediments. Analyst, 101(1200): 187-197.

Benitez-Nelson, C., O'Neill, L., Kolowith, L.C., Pellechia, P., Thunell, R., 2004. Phosphonates and particulate organic phosphorus cycling in an anoxic marine basin. Limnology and Oceanography, 49(5): 1593-1604.

Benitez-Nelson, C.R., 2000. The biogeochemical cycling of phosphorus in marine systems. Earth-Science Reviews, 51(1): 109-135.

Benitez-Nelson, C.R., Madden, L.P.N., Styles, R.M., Thunell, R.C., Astor, Y., 2007. Inorganic and organic sinking particulate phosphorus fluxes across the oxic/anoxic water column of Cariaco Basin, Venezuela. Marine Chemistry, 105(1): 90-100.

Bernhardt, H., Wilhelms, A., 1967. The continuous determination of low level iron, soluble phosphate and total phosphate with the AutoAnalyzer, Technicon Symposia, pp. 385-389.

Bertilsson, S., Berglund, O., Karl, D.M., Chisholm, S.W., 2003. Elemental composition of marine Prochlorococcus and Synechococcus: Implications for the ecological stoichiometry of the sea. Limnology and Oceanography, 48(5): 1721-1731.

Brown, Z.W., Casciotti, K.L., Pickart, R.S., Swift, J.H., Arrigo, K.R., 2015. Aspects of the marine nitrogen cycle of the Chukchi Sea shelf and Canada Basin. Deep Sea Research Part II: Topical Studies in Oceanography(0).

Brugler, E.T. et al., 2014. Seasonal to interannual variability of the Pacific water boundary current in the Beaufort Sea. Progress in Oceanography, 127: 1-20.

Coachman, L.K., Aagaard, K., Tripp, R.B., 1975. Bering Strait: the regional physical oceanography. University of Washington Press. 
Cooney, R., Coyle, K., 1982. Trophic implications of cross-shelf copepod distributions in the southeastern Bering Sea. Marine Biology, 70(2): 187-196.

Cota, G. et al., 1996. Nutrients, primary production and microbial heterotrophy in the southeastern Chukchi Sea: Arctic summer nutrient depletion and heterotrophy. Marine ecology progress series. Oldendorf, 135(1): 247-258.

Dyhrman, S. et al., 2006. Phosphonate utilization by the globally important marine diazotroph Trichodesmium. Nature, 439(7072): 68-71.

Ehn, J., Granskog, M.A., Reinart, A., Erm, A., 2004. Optical properties of melting landfast sea ice and underlying seawater in Santala Bay, Gulf of Finland. Journal of Geophysical Research: Oceans (1978-2012), 109(C9).

Elser, J.J. et al., 2000. Nutritional constraints in terrestrial and freshwater food webs. Nature, 408(6812): 578-580.

Frey, K. et al., 2014. Graduate School of Geography, Clark University, Worcester, MA, USA 2 Cryospheric Sciences Laboratory, NASA Goddard Space Flight Center, Greenbelt, MD, USA 3 Chesapeake Biological Laboratory, University of Maryland Center for Environmental Science, Solomons, MD, USA 4 Institute of Marine Research, Tromsø, Norway 5 Graduate School of Fisheries Sciences, Hokkaido University, Hokkaido, Japan.

Galloway, J. et al., 1996. Nitrogen and phosphorus budgets of the North Atlantic Ocean and its watershed, Nitrogen Cycling in the North Atlantic Ocean and its Watersheds. Springer, pp. 3-25.

Garrison, D.L., Sullivan, C.W., Ackley, S.F., 1986. Sea ice microbial communities in Antarctica. BioScience: 243-250.

Geider, R.J., La Roche, J., 2002. Redfield revisited: variability of C : N : P in marine microalgae and its biochemical basis. European Journal of Phycology, 37(1): 117.

Gong, D., Pickart, R.S., 2015. Summertime circulation in the eastern Chukchi Sea. Deep Sea Research Part II: Topical Studies in Oceanography.

Gordeev, V., Martin, J., Sidorov, I., Sidorova, M., 1996. A reassessment of the Eurasian river input of water, sediment, major elements, and nutrients to the Arctic Ocean. American Journal of Science, 296(6): 664-691.

Gosselin, M., Levasseur, M., Wheeler, P.A., Horner, R.A., Booth, B.C., 1997. New measurements of phytoplankton and ice algal production in the Arctic Ocean. Deep Sea Research Part II: Topical Studies in Oceanography, 44(8): 1623-1644.

Gradinger, R., Ikävalko, J., 1998. Organism incorporation into newly forming Arctic sea ice in the Greenland Sea. Journal of Plankton Research, 20(5): 871-886.

Grebmeier, J.M., 2012. Shifting patterns of life in the Pacific Arctic and sub-Arctic Seas. Marine Science, 4.

Hameedi, M.J., 1978. Aspects of water column primary productivity in the Chukchi Sea during summer. Marine Biology, 48(1): 37-46.

Hill, V., Cota, G., Stockwell, D., 2005. Spring and summer phytoplankton communities in the Chukchi and Eastern Beaufort Seas. Deep Sea Research Part II: Topical Studies in Oceanography, 52(24-26): 3369-3385.

Ho, T.-Y. et al., 2003. THE ELEMENTAL COMPOSITION OF SOME MARINE PHYTOPLANKTON1. Journal of Phycology, 39(6): 1145-1159. 
Holland, M.M., Bitz, C.M., Tremblay, B., 2006. Future abrupt reductions in the summer Arctic sea ice. Geophysical Research Letters, 33(23).

Holm-Hansen, O., Lorenzen, C.J., Holmes, R.W., Strickland, J.D., 1965. Fluorometric determination of chlorophyll. Journal du Conseil, 30(1): 3-15.

Holmes, R.M. et al., 2012. Seasonal and annual fluxes of nutrients and organic matter from large rivers to the Arctic Ocean and surrounding seas. Estuaries and Coasts, 35(2): 369-382.

Huang, X.-L., Zhang, J.-Z., 2010. Spatial variation in sediment-water exchange of phosphorus in Florida Bay: AMP as a model organic compound. Environmental science \& technology, 44(20): 7790-7795.

Karl, D. et al., 1997. The role of nitrogen fixation in biogeochemical cycling in the subtropical North Pacific Ocean. Nature, 388(6642): 533-538.

Karl, D.M., 2014. Microbially mediated transformations of phosphorus in the sea: New views of an old cycle. Annual Review of Marine Science, 6: 279-337.

Kérouel, R., Aminot, A., 1997. Fluorometric determination of ammonia in sea and estuarine waters by direct segmented flow analysis. Marine Chemistry, 57(3): 265-275.

Koroleff, F., 1983. Simultaneous oxidation of nitrogen and phosphorus compounds by persulfate. Methods of seawater analysis, 2: 205-206.

Le Fouest, V., Babin, M., Tremblay, J.É., 2013. The fate of riverine nutrients on Arctic shelves. Biogeosciences, 10(6): 3661-3677.

Leu, E., Søreide, J., Hessen, D., Falk-Petersen, S., Berge, J., 2011. Consequences of changing sea-ice cover for primary and secondary producers in the European Arctic shelf seas: timing, quantity, and quality. Progress in Oceanography, 90(1): 18-32.

Martin, P., Dyhrman, S.T., Lomas, M.W., Poulton, N.J., Van Mooy, B.A., 2014. Accumulation and enhanced cycling of polyphosphate by Sargasso Sea plankton in response to low phosphorus. Proceedings of the National Academy of Sciences, 111(22): 8089-8094.

Martiny, A.C. et al., 2013. Strong latitudinal patterns in the elemental ratios of marine plankton and organic matter. Nature Geoscience, 6(4): 279-283.

Melnikov, I.A., Kolosova, E.G., Welch, H.E., Zhitina, L.S., 2002. Sea ice biological communities and nutrient dynamics in the Canada Basin of the Arctic Ocean. Deep Sea Research Part I: Oceanographic Research Papers, 49(9): 1623-1649.

Mills, M.M. et al., 2015. Impacts of low phytoplankton NO 3-: PO 4 3- utilization ratios over the Chukchi Shelf, Arctic Ocean. Deep Sea Research Part II: Topical Studies in Oceanography.

Monaghan, E., Ruttenberg, K., 1999. Dissolved organic phosphorus in the coastal ocean: Reassessment of available methods and seasonal phosphorus profiles from the Eel River Shelf. Limnology and Oceanography, 44(7): 1702-1714.

Monterey, G., Levitus, S., 1997. Climatological cycle of mixed layer depth in the world ocean. US Government Printing Office, NOAA NESDIS, 5.

Mortazavil, B., Iversonl, R.L., Landing, W.M., Huang, W., 2000. Phosphorus budget of Apalachicola Bay: a river-dominated estuary in the northeastern. Mar Ecol Prog Ser, 198: 33-42. 
Münchow, A., Weingartner, T.J., Cooper, L.W., 1999. The summer hydrography and surface circulation of the East Siberian shelf sea*. Journal of Physical Oceanography, 29(9): 2167-2182.

Nikolopoulos, A. et al., 2009. The western Arctic boundary current at $152 \mathrm{~W}$ : Structure, variability, and transport. Deep Sea Research Part II: Topical Studies in Oceanography, 56(17): 1164-1181.

Nomura, D., McMinn, A., Hattori, H., Aoki, S., Fukuchi, M., 2011. Incorporation of nitrogen compounds into sea ice from atmospheric deposition. Marine Chemistry, 127(1): 90-99.

Orchard, E.D., Benitez-Nelson, C.R., Pellechia, P.J., Lomas, M.W., Dyhrman, S.T., 2010. Polyphosphate in Trichodesmium from the low-phosphorus Sargasso Sea. Limnology and Oceanography, 55(5): 2161-2169.

Paytan, A., McLaughlin, K., 2007. The oceanic phosphorus cycle. Chemical Reviews, 107(2): 563-576.

Petrenko, D., Pozdnyakov, D., Johannessen, J., Counillon, F., Sychov, V., 2013. Satellitederived multi-year trend in primary production in the Arctic Ocean. International Journal of Remote Sensing, 34(11): 3903-3937.

Pickart, R.S., 2004. Shelfbreak circulation in the Alaskan Beaufort Sea: Mean structure and variability. Journal of Geophysical Research: Oceans (1978-2012), 109(C4).

Post, E. et al., 2013. Ecological consequences of sea-ice decline. Science, 341(6145): 519-524.

Redfield, A.C., 1958. The biological control of chemical factors in the environment. American scientist: 230A-221.

Reimnitz, E., Marincovich Jr, L., McCormick, M., Briggs, W., 1992. Suspension freezing of bottom sediment and biota in the Northwest Passage and implications for Arctic Ocean sedimentation. Canadian Journal of Earth Sciences, 29(4): 693-703.

Ruttenberg, K., 2003. The global phosphorus cycle. Treatise on geochemistry, 8: 585643.

Schumacher, J., Reed, R., 1986. On the Alaska coastal current in the western Gulf of Alaska. Journal of Geophysical Research: Oceans (1978-2012), 91(C8): 96559661.

Serreze, M.C., Holland, M.M., Stroeve, J., 2007. Perspectives on the Arctic's shrinking sea-ice cover. Science, 315(5818): 1533-1536.

Shimada, K., Carmack, E.C., Hatakeyama, K., Takizawa, T., 2001. Varieties of shallow temperature maximum waters in the western Canadian Basin of the Arctic Ocean. Geophysical Research Letters, 28(18): 3441-3444.

Souza, A.C., Gardner, W.S., Dunton, K.H., 2014. Rates of nitrification and ammonium dynamics in northeastern Chukchi Sea shelf waters. Deep Sea Research Part II: Topical Studies in Oceanography, 102(0): 68-76.

Steele, M. et al., 2004. Circulation of summer Pacific halocline water in the Arctic Ocean. Journal of Geophysical Research: Oceans, 109(C2): C02027.

Stroeve, J.C. et al., 2012. Trends in Arctic sea ice extent from CMIP5, CMIP3 and observations. Geophysical Research Letters, 39(16).

Sylvan, J.B. et al., 2006. Phosphorus limits phytoplankton growth on the Louisiana shelf during the period of hypoxia formation. Environmental science \& technology, 40(24): 7548-7553. 
Torres-Valdés, S. et al., 2013. Export of nutrients from the Arctic Ocean. Journal of Geophysical Research: Oceans, 118(4): 1625-1644.

Twining, B.S., Baines, S.B., Fisher, N.S., 2004. Element stoichiometries of individual plankton cells collected during the Southern Ocean Iron Experiment (SOFeX). Limnology and Oceanography, 49(6): 2115-2128.

Tyrrell, T., 1999. The relative influences of nitrogen and phosphorus on oceanic primary production. Nature, 400(6744): 525-531.

von Appen, W.-J., Pickart, R.S., 2012. Two configurations of the western Arctic shelfbreak current in summer. Journal of Physical Oceanography, 42(3): 329-351.

Walsh, J. et al., 1989. Carbon and nitrogen cycling within the Bering/Chukchi Seas: source regions for organic matter effecting AOU demands of the Arctic Ocean. Progress in Oceanography, 22(4): 277-359.

Wang, M., Overland, J.E., 2009. A sea ice free summer Arctic within 30 years? Geophysical Research Letters, 36(7).

Weber, T.S., Deutsch, C., 2010. Ocean nutrient ratios governed by plankton biogeography. Nature, 467(7315): 550-554.

Weingartner, T. et al., 2005. Circulation on the north central Chukchi Sea shelf. Deep Sea Research Part II: Topical Studies in Oceanography, 52(24): 3150-3174.

Yamamoto-Kawai, M., Carmack, E., McLaughlin, F., 2006. Nitrogen balance and Arctic throughflow. Nature, 443(7107): 43-43.

Zhang, J.-Z., Guo, L., Fischer, C.J., 2010. Abundance and chemical speciation of phosphorus in sediments of the Mackenzie River Delta, the Chukchi Sea and the Bering Sea: importance of detrital apatite. Aquatic geochemistry, 16(3): 353-371. 